\title{
Estimating water erosion from the brightness index of orbital images: A framework for the prognosis of degraded pastures
}

\section{Alessandra Soares Vieira ${ }^{a}$, Renato Farias do Valle Junior ${ }^{\text {b,f }}$, Vinicius Silva Rodrigues ${ }^{\text {b }}$, Thiago Luiz da Silva Quinaia ${ }^{\mathrm{b}}$, Rafaella Gouveia Mendes ${ }^{\mathrm{b}}$, Carlos Alberto Valera ${ }^{\mathrm{c}, \mathrm{f}}$, Luís Filipe Sanches Fernandes d,f , Fernando António Leal Pacheco e,f,*}

a Federal University of Triângulo Mineiro, Institute of Technological and Exact Sciences (ICTE), Uberaba, MG 38015-360, Brazil

${ }^{\mathrm{b}}$ Federal Institute of Triângulo Mineiro, Uberaba Campus, Geoprocessing Laboratory, Uberaba, MG 38064-790, Brazil

c Coordenadoria Regional das Promotorias de Justiça do Meio Ambiente das Bacias dos Rios Paranaíba e Baixo Rio Grande, Rua Coronel Antônio Rios, 951, Uberaba, MG 38061-150, Brazil

d Center for Research and Agro-environmental and Biological Technologies, University of Trás-os-Montes e Alto Douro, Ap. 1013, 5001-801 Vila Real, Portugal

e Center of Chemistry of Vila Real, University of Trás-os-Montes e Alto Douro, Ap. 1013, 5001-801 Vila Real, Portugal

${ }^{\mathrm{f}}$ POLUS-Grupo de Política de Uso do Solo, Universidade Estadual Paulista (UNESP), Via de Acesso Prof. Paulo Donato Castellane, s/n, Jaboticabal SP 14884-900, Brazil

\section{H I G H L I G H T S}

- Inadequate soil management and absence of conservation favored pasture degradation.

- The brightness of Landsat 8 images robustly described soil losses in the study area.

- A nexus exist between brightness, soil erosion and pasture degradation.

- The developed Google Earth Engine script assesses the nexus on a global scale.

\section{A R T I C L E I N F O}

\section{Article history:}

Received 19 December 2020

Received in revised form 15 February 2021

Accepted 16 February 2021

Available online 23 February 2021

Editor: Damia Barcelo

\section{Keywords:}

Water erosion

Brightness index

Pasture degradation

Environmental land use conflict

Geographic information system

"Polluter-pays principle"

\section{G R A P H I C A L A B S T R A C T}

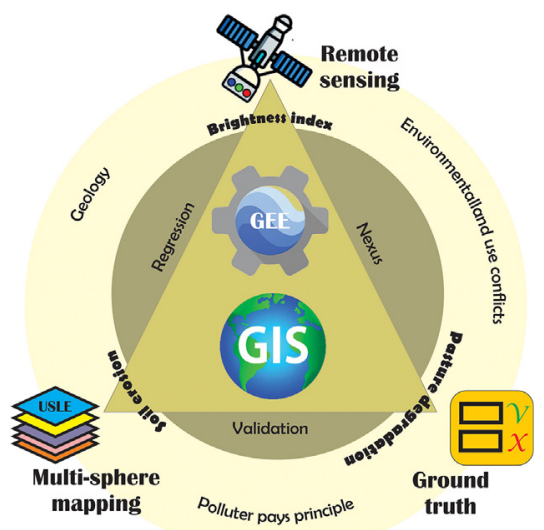

A B S T R A C T

The inadequate management of soils and the absence of conservation practices favor the degradation of pastures and can trigger adverse environmental alterations and damage under the terms of Brazilian Federal Law no. $6.938 / 1981$. Based on this premise, this study aimed to estimate soil losses caused by water erosion in pasture areas using the brightness index (BI) from the annual series of Landsat 8 images in different geological formations. A specifically prepared Google Earth Engine (GEE) script automatically extracted the BI from the images. The study occurred in the Environmental Protection Area (EPA) of Uberaba River basin (Minas Gerais, Brazil). To accomplish the goal, 180 digital 500-wide random buffers were selected from 3 geologic types (60 points per type), and then analyzed for zonal statistics of USLE (Universal Soil Loss Equation) soil loss and BI in a Geographic Information System. The regression models BI versus USLE soil loss allowed estimating BI soil losses over the pastures of EPA. The model fittings were remarkable. The validation of soil loss maps in the EPA occurred in pasture phytophysiognomies through the probing of penetration resistance in 37 randomly selected locations. The results were satisfactory, mostly those based on the BI. The BI losses increased for greater resistances. Amplified losses also occurred in regions exposed to environmental land use conflicts (actual uses that deviate from land capability or natural use). Overall, the BI approach proved efficient to accurately track soil losses and pasture

\footnotetext{
* Corresponding author.

E-mail addresses: alessandra.vieira@uftm.edu.br (A.S. Vieira), renato@iftm.edu.br (R.F. do Valle Junior), carlosvalera@mpmg.mp.br (C.A. Valera), lfilipe@utad.pt (L.F.S. Fernandes), fpacheco@utad.pt (F.A.L. Pacheco).
} 
degradation over large areas, with the advantage of standing on a single parameter easily accessed through remote sensed data. From an environmental standpoint, this is an important result, because the accurate diagnosis and prognosis of degraded pastures is paramount to implement mitigation measures following the "polluter pays principle", even more in Brazil where the areas occupied by degraded pastures are enormous.

(c) 2021 Elsevier B.V. All rights reserved.

\section{Introduction}

Pastures represent nearly $70 \%$ of the world's agricultural area, which occupies some $26 \%$ of solid Earth (http://fao.org). In Brazil, pastures occupy 179 million hectares of rural land (Parente et al., 2017), but 70\% of this area evidences some degree of degradation. Exposed soil is among the most important features of pasture degradation (Tepanosyan et al., 2017), together with invasive foliage and termite nests (Galdino, 2012). Pasture degradation is a source of global concern, because it leads to erosion and affects the carbon storage capacity of soils (Torres et al., 2019), among other environmental consequences.

The causes of pasture degradation may be natural but in managed landscapes are mostly anthropic. Inadequate soil management combined with the absence of conservation practices are common anthropic causes of this phenomenon. An important consequence of pasture degradation is productivity decline, but the environmental impacts are also noteworthy. As mentioned, they include amplified erosion and carbon emissions from the soil (Nesper et al., 2015), but are not limited to these problems. Erosion promotes the reduction of nutrients in the soil surface and their leaching to rivers and lakes causing eutrophication and threats to aquatic life. Recently, several studies have demonstrated the effect of erosion on the quality of surface water due to nutrient leaching (Fernandes et al., 2012; Lopes et al., 2021; Oliveira et al., 2019; Xu and Zhang, 2016), even when protected by riparian forests (Pissarra et al., 2019; Valera et al., 2019).

Adequate management and conservation practices are essential to minimize erosion and the related adverse effects. A fundamental issue in that regard is the respect of current land uses for land suitability (natural or ideal use), guided by the physicochemical characteristics of soils and landscapes (Costa et al., 2019). This harmony between current and natural use avoids the generation of environmental land use conflicts (Valle Junior et al., 2013, 2014). Conversely, the disrespect for land suitability can negatively affect the natural ecosystems. This include water quality degradation (Pacheco and Sanches Fernandes, 2016; Valle et al., 2014; Valle Junior et al., 2015b), soil fertility (Novara et al., 2018; Valera et al., 2016) and biodiversity (Sanches Fernandes et al., 2018; Valle Junior et al., 2015a) declines, or amplification of flood risks (Caldas et al., 2018).

The adequate management and conservation practices are the routes to sustainable pasturing, but their implementation is likely more successful when the condition of soil is known in advance. This includes information on water erosion and soil erodibility. The estimation of erosion and erodibility indicators frequently resorts to in loco evaluation of penetration resistance or organic carbon (field approach), rain simulators (experimental approach) or equations (empirical approach). In general, the empirical approach is suited for regional-scale studies, but lacks resolution at the local scale. Conversely, the field and experimental approaches are detailed enough for local assessments but hardly applicable to the regional scale.

For the empirical approach there are several models available, the most widespread being the Universal Soil Loss Equation (USLE) (Wischmeier and Smith, 1978) that has been revised (USLER) (Renard et al., 1997) and modified (USLEM) (Williams, 1975). With the evolution of geographic information systems (GIS) and remote sensing, coupled with the launch of Google Earth Engine (https:// earthengine.google.com) platform in 2010 , it is possible to generate and display the spatial distribution of features observed in satellite images over different time scales (Dong et al., 2016). These emergent technologies and data allowed diagnosing many natural and anthropogenic processes, including pasture degradation (Valle Júnior et al., 2019). Other studies quantified the extent of erosion (Bhargava et al., 2020), forecasted land cover changes above the eroded pasture (El Jazouli et al., 2019), or predicted the risk of erosion from a spatial multi criteria analysis (Assefa et al., 2015; Mhiret et al., 2019). More complex assessments combined the previous techniques with multivariate statistical analyses with the purpose to set up and display a network of causal links between physicochemical parameters of soil and water, land uses, and pasture degradation (Oliveira et al., 2019). The emerging remote sensing techniques have also been used to relate the intensity of erosion with the brightness index of satellite images, derived from the Tasseled Cap transformation (Rodrigues et al., 2019; Saadat et al., 2014), where highly degraded soils have higher brightness than conserved soils (Bachaoui et al., 2014; Bannari et al., 2016).

Despite the abundant literature on the field, experimental and empirical estimation of erosion; on the relationship between brightness index and erosion; and on the role of pasture degradation on erosion, to our best knowledge the studies integrating multiple views (e.g., remote sensed, cartographic and field data) are still uncommon. The advantage of a multiple approach research is that having accomplished consistent results among the various methods, we are more confident to quantify erosion and the related matters from a single view. In the context of pasture degradation assessments and implementation of adequate conservation measures, the quantification of soil erosion from remote sensed data (brightness index) is preferable given its automation capacity and hence applicability to very large (e.g., global) areas. Therefore, the present study sought to estimate soil losses by water erosion in areas of degraded pastures, using the Universal Soil Loss Equation (USLE) and the brightness index (BI) estimated from an assortment of Landsat 8 images, checking both results in the field using the penetration resistance as indicator. The study has properly handled and interpreted the heterogeneity across geologic formations and the role of environmental land use conflicts. Finally, a script was created on the GEE platform, with the aim of methodologically automating the estimation of erosion losses from the brightness index of Landsat 8 images.

\section{Material and methods}

\subsection{Study area}

The study area comprises the Environmental Protection Area of Uberaba River (EPA; protected by Minas Gerais State Law no. 13183/ 1999), located in the municipality of Uberaba, Triângulo Mineiro region, state of Minas Gerais (Fig. 1). The EPA is relevant because of its native forest remnants and water resources. The water resources are used for the public supply of Uberaba city, with nearly 260,000 inhabitants (http://www.ibge.gov.br). The area is centered on the latitude $19^{\circ} 45^{\prime}$ $27^{\prime \prime} \mathrm{S}$ and longitude $47^{\circ} 55^{\prime} 36^{\prime \prime} \mathrm{W}$, covering a surface of approximately 52,810 ha. The altitudes range from 522 to $1031 \mathrm{~m}$. The regional climate is tropical, hot and rainy between October and March, and cold and dry between April and September, with an annual average temperature between 20 and $24{ }^{\circ} \mathrm{C}$ and an average precipitation between 1300 and $1700 \mathrm{~mm} /$ year (Cruz, 2003). The flat to smoothly undulated landscapes characterize the local topography, integrated regionally in the so-called 


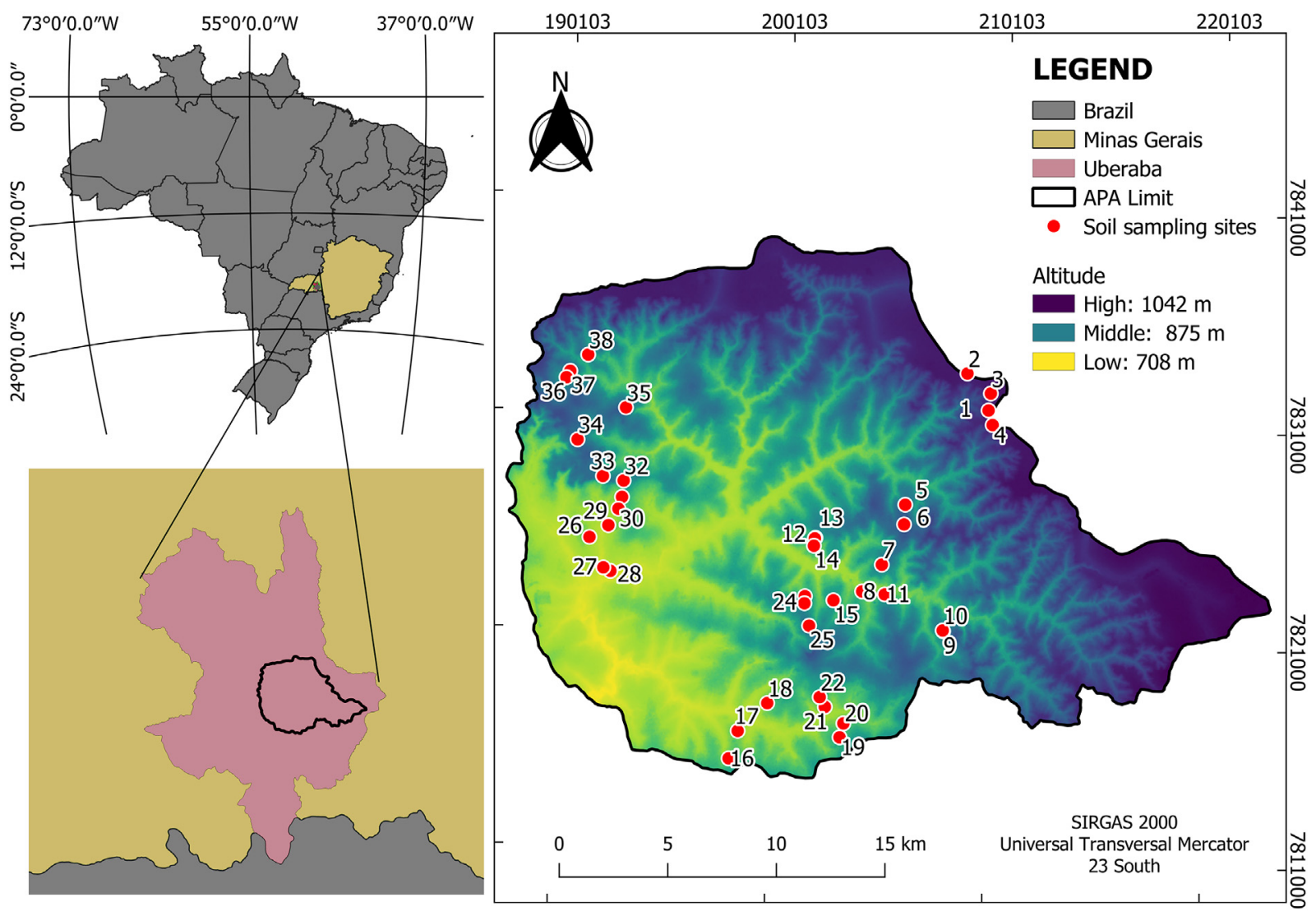

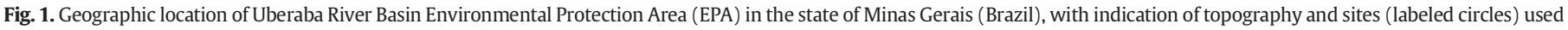
to validate the cartographic-based soil loss estimates (based on the USLE and brightness index approaches).

basalt-sandstone plateau of Parana River basin located in the north/ northeast portions that sedimentary watershed. The sedimentary rocks comprise sandstones of Uberaba and Marília formations (Bauru Group from the Cretaceous), which overlay the basalts of Serra Geral Formation (São Bento Group) (Fig. 2). The predominant soil coverage is by Oxisols with varying levels of fertility (Valle Junior et al., 2013). Pasture degradation has affected soil fertility, the prominent land use in the EPA (50.9\%), as documented in Valle Júnior et al. (2019).

\subsection{Acquisition and generation of data}

The geographic data necessary for the present study comprise soil losses estimated by the USLE and brightness index (BI) methods as well as environmental land use conflicts determined from differences of actual and ideal land uses. The base information required to produce these data comprehended rainfall records, soil data and a digital elevation model to estimate the USLE soil losses and their factors. It also included Landsat 8 images to generate the brightness index necessary to derive the BI soil losses. It finally integrated land use and cover, land suitability and geologic maps, to extract pasture areas as well as geologic formations and identify environmental land use conflicts inside them. Table 1 depicts the institutional sources of base information and their website addresses. A re-projection of all geographical data onto the Geocentric Reference System for the Americas (SIRGAS) occurred according to IBGE resolution 1/2005.

\subsection{Soil loss assessments (BI and USLE)}

The Universal Soil Loss Equation (USLE) assessed the spatial distribution of soil losses in the EPA of Uberaba River basin. According to
Barbosa et al. (2015), the USLE is valid for qualitative studies of sheet erosion and applicable on the regional scale. The factors used to predict soil loss by sheet erosion are rain erosivity $\left(\mathrm{R}, \mathrm{MJ} \mathrm{mm} \mathrm{h} \mathrm{ma}^{-1} \mathrm{hear}^{-1}\right)$, soil erodibility $\left(\mathrm{K}\right.$, ton $\left.\mathrm{h} \mathrm{MJ} \mathrm{J}^{-1} \cdot \mathrm{mm}^{-1}\right)$, topographic factor $(\mathrm{L} \times \mathrm{S}$, dimensionless) and the management and conservation practices factor (CP, dimensionless), in keeping with Eq. (1) (Wischmeier and Smith, 1978):

$\mathrm{A}=\mathrm{R} \times \mathrm{K} \times(\mathrm{L} \times \mathrm{S}) \times \mathrm{CP}$

where $\mathrm{A}\left(\mathrm{t}\right.$ ha $\mathrm{a}^{-1}$ year $^{-1}$ ) is the soil loss. The $\mathrm{R}$ factor determines the rain's ability to cause erosion, being the product of total kinetic energy and maximum intensity of rain over a 30 -minutes period $\left(\mathrm{EI}_{30}\right)$. In this study, the R factor was estimated using the software Net Erosividade MG (Moreira et al., 2008) and daily rainfall data. A number of discrete $\mathrm{R}$-values estimated for several meteorological stations and interpolated using Qgis 3.4 software (https://www.qgis.org), allowed producing a raster map for the $\mathrm{R}$ within the EPA. Then, the software used the EPA limit as layer mask to clip the map, retaining the $\mathrm{R}$ factor information inside this boundary.

Soil erodibility values (K) came from the work of Valle Junior (2008), who indirectly estimated this factor for the Uberaba River basin using the techniques of Ribeiro (2007) and Chaves (1994). The adopted $\mathrm{K}$ values were 0.028 for red yellow argisol, 0.029 for red argisol, 0.0044 for melanic gleysol, 0.02 for red yellow latosol, 0.017 for dystrophic red latosol, 0.022 for dystropherric red latosol. The clipping step, as previously applied to the $\mathrm{R}$ factor, retained the $\mathrm{K}$ values inside the EPA.

The LS factor estimated as the product of slope length (L) and slope steepness ( $\mathrm{S}$ ) factors, resulted from the processing of an EPA's digital elevation model in the Qgis 3.4 using the proper tools. The L factor 


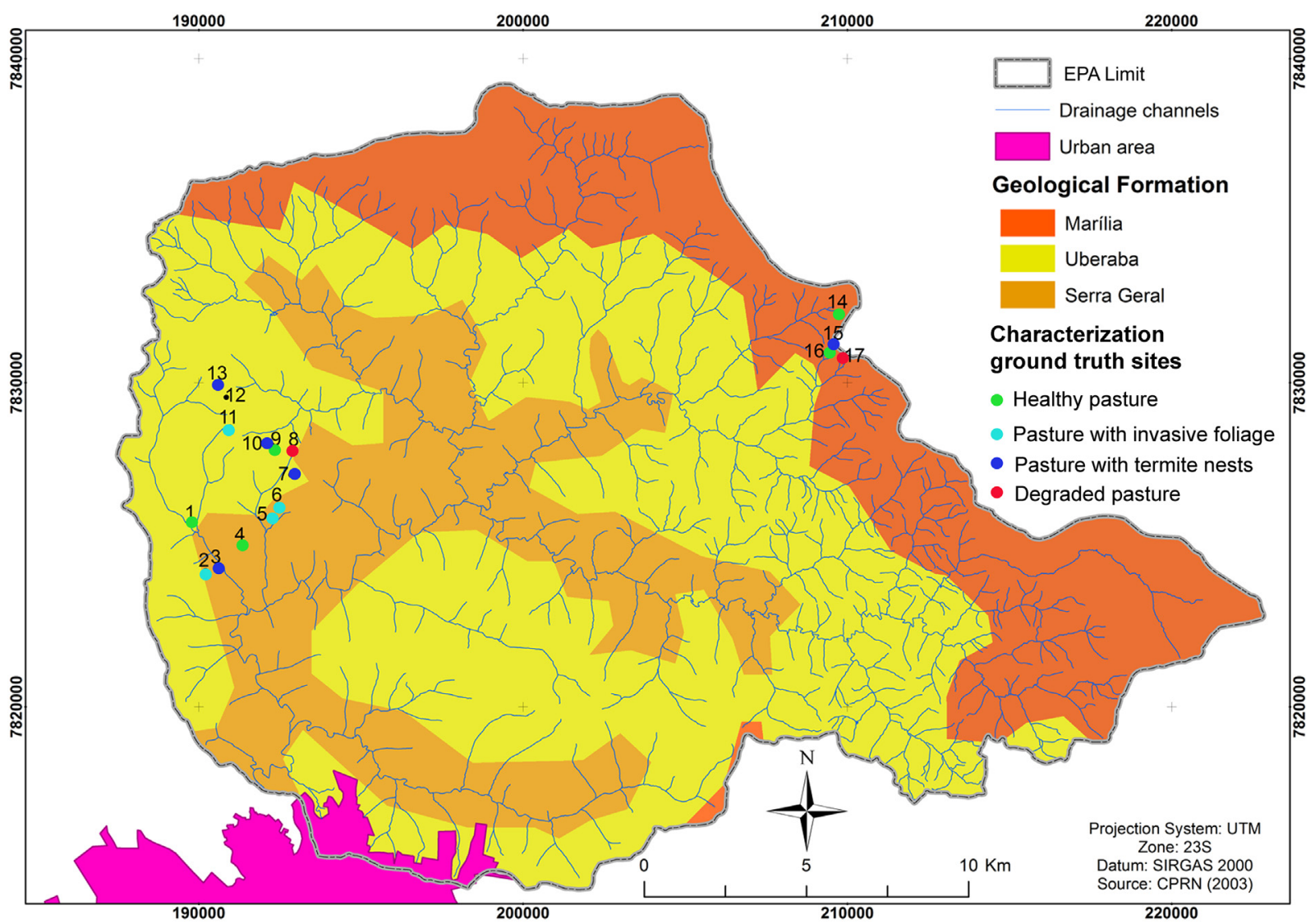

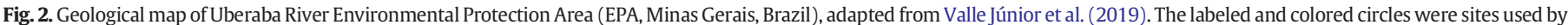

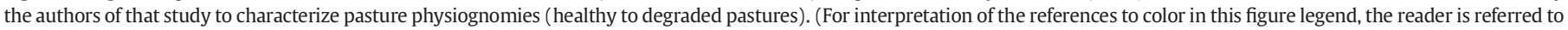
the web version of this article.)

represents the relationship between expected and actual soil losses on a 22.13-meter long hillslope (Desmet and Govers, 1996):

$L_{i j}=\frac{\left[\left(A_{i j-i n}+D^{2}\right)^{m+1}-\left(A_{i j-i n}\right)^{m+1}\right]}{\left[D^{m+2} \cdot x_{i j}{ }^{m} \cdot(22.13)^{m}\right]}$

where $L_{i j}$ is the slope length factor of a pixel located at the ij coordinates; $A_{i j-i n}$ is the contributing area of that pixel; $\mathrm{D}$ is the pixel size in meters; $\mathrm{x}$ is the shape coefficient ( $\mathrm{x}=1$ for pixelated systems); and $\mathrm{m}$ is the exponent of slope length.

The $\mathrm{S}$ factor, on the other hand, describes the ratio of expected and actual soil losses on a 9\% hillslope (Mccool et al., 1987):

$S=10.8 \cdot \sin \sin \theta_{i j}+0.03$, if $\tan \theta_{i j}<0.09$

$S=16.8 \cdot \sin \sin \theta_{i j}-0.5$, if $\tan \theta_{i j}>0.09$

where $\theta_{i j}$ is the slope angle of pixel $i j$ in radians.

\section{Table 1}

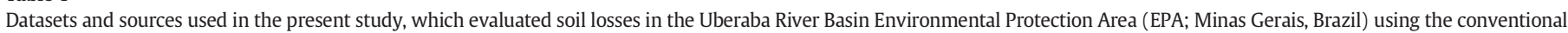
Universal Soil Loss Equation (USLE) and brightness index (BI) model based on Landsat 8 imagery, concomitantly evaluating the role of environmental land use conflicts.

\begin{tabular}{|c|c|c|c|}
\hline Type of data & Usage in the present study & Source & URL \\
\hline $\begin{array}{l}\text { Point shapefile of rainfall stations and } \\
\text { associated data }\end{array}$ & To generate the $\mathrm{R}$ factor for the USLE in the EPA & $\begin{array}{l}\text { Produced by the } \\
\text { author through GIS }\end{array}$ & - \\
\hline Soil map of Minas Gerais state & To generate the $\mathrm{K}$ factor for the USLE in the EPA & $\begin{array}{l}\text { State System of } \\
\text { Environment and } \\
\text { Water Resources }\end{array}$ & http://idesisema.meioambiente.mg.gov.br/ \\
\hline $\begin{array}{l}\text { Digital Elevation Model with } 30 \mathrm{~m} \text { of } \\
\text { resolution }\end{array}$ & $\begin{array}{l}\text { To generate the L and S factors for the USLE in } \\
\text { the EPA }\end{array}$ & $\begin{array}{l}\text { United States Geo- } \\
\text { logical Survey }\end{array}$ & https://earthexplorer.usgs.gov/ \\
\hline $\begin{array}{l}\text { Landsat } 8 \text { Orbital Images with } 30 \text { m of } \\
\text { average resolution: } 12 \text { images from } 2018 \\
\text { with }<30 \% \text { clouds }\end{array}$ & $\begin{array}{l}\text { To obtain brightness index in the EPA using } \\
\text { Google Earth Engine programming }\end{array}$ & $\begin{array}{l}\text { Google Earth } \\
\text { Engine }\end{array}$ & https://earthengine.google.com/ \\
\hline $\begin{array}{l}\text { Land use and cover map ( } 30 \times 30 \text { m pixel) } \\
\text { generated from Landsat images in Google } \\
\text { Earth Engine - MAPBIOMAS }\end{array}$ & $\begin{array}{l}\text { To delineate the pasture areas and evaluate the } \\
\text { environmental land use conflicts in the EPA }\end{array}$ & $\begin{array}{l}\text { Google Earth } \\
\text { Engine }\end{array}$ & $\begin{array}{l}\text { https://code.earthengine.google.com/? } \\
\text { accept_repo=users\%2Fmapbiomas\% } \\
\text { 2Fuser-toolkit\&scriptPath=users\%2Fmapbiomas\% } \\
\text { 2Fuser-toolkit\%3Amapbiomas-user-toolkit-download.js }\end{array}$ \\
\hline Land use suitability map & $\begin{array}{l}\text { To evaluate the environmental land use } \\
\text { conflicts in the EPA }\end{array}$ & $\begin{array}{l}\text { Adapted from Valle } \\
\text { Junior (2008) }\end{array}$ & - \\
\hline Geological map of Minas Gerais state & $\begin{array}{l}\text { To discriminate soil losses and environmental } \\
\text { land use conflicts among different geologic } \\
\text { types cropping out in the EPA }\end{array}$ & $\begin{array}{l}\text { State System of } \\
\text { Environment and } \\
\text { Water Resources }\end{array}$ & http://idesisema.meioambiente.mg.gov.br/ \\
\hline
\end{tabular}


To obtain the CP factor in the study area, we used the map of land uses and covers (LULC) available for the year of 2018. The download was from the website of Map Biomas Alerta Project, Collection 4.1 (http://mapbiomas.org). The LULC cartography has the detail of a 30meter scale and production resorted to automatic classification procedures applied to Landsat 8 images. The conversion of LULC classes into the management and conservation practices factors was based on Stein et al. (1987): 0.00004 for forest formation, 0.0007 for savanna formation, 0.0001 for planted forest, 0.01 for field formation, 0.01 for pasture, 0.25 for annual and perennial crops, 0.05 for semi-perennial crops, 0 for urban infrastructure, 0 for other non-vegetated area.

The Tasseled Cap transformation, developed by Kauth and Thomas (1976) at the Michigan Environmental Research Institute (ERIM), is capable to map changes in vegetation using satellite sensors, and hence to compare soil covers over time. The method reduces the data of various multispectral bands into a set of three main components, called brightness, greenness, and wetness (Zanchetta et al., 2016). Brightness can differentiate levels of soil erosion in various land use classes (Bannari et al., 2016) and indicate the state of degradation where leached soils tend to be brighter than organically-rich soils (Bachaoui et al., 2014). The Google Earth Engine (GEE) generated the brightness index (BI) within the EPA for the year 2018 using Eq. (5):

$\mathrm{BI}=($ blue*0.3029 $)+($ green*0.2786) $+(\operatorname{red} * 0.4733)$

$+($ NIR $1 * 0.5599)+($ SWIR1*0.508 $)+($ SWIR2*0.1872 $)$

where the terms "blue", "green", "red", "NIR1", "SWIR1" and "SWIR2" are spectral bands represented by dimensionless digital numbers. The BI was calculated for 11 Landsat 8 images selected throughout the year from the orbit/point (220/074), with a resolution of $30 \mathrm{~m}$ and a percentage of clouds $<30 \%$. After calculating the BI for each image, the GEE exported the results as GIS format (11 BI raster maps). The Appendix A presents the script developed to perform all GEE operations, while Fig. 3 illustrates the workflow. The processing of BI maps in Qgis3.4 using the raster calculator tool allowed obtaining the average BI map representing the 11 maps generated for the year 2018. The boundaries of pastureland in each geological formation allowed clipping the average $\mathrm{BI}$ map restraining it to the relevant areas.

A random selection of 60 locations per geology, with a minimum distance of $500 \mathrm{~m}$ from each other, allowed creating a dataset of points within the EPA. The random point selection used a tool of Qgis 3.4, and other tools enabled generating 20-meter buffers around the points and obtaining average soil loss (USLE) and brightness index scores from inside the buffers using zonal statistics and the corresponding maps. For each geologic type, least squares regression based on the GLM procedure of MINITAB (https://www.minitab.com) set up relationships between the average values of soil loss and brightness index. Soil losses derived from these relationships and interpolated over the EPA represent the model of BI soil losses for the region.

\subsection{Environmental land use conflicts}

The concept of environmental land use conflict refers to the disagreement between the ideal use (suitability) and the actual land use. The diagnosis of suitability stands on the roughness coefficient (RN) methodology, widely demonstrated in the works of Rocha and Kurtz (2001), Valle Junior (2008) and Valle et al. (2014). The RN coefficient is the product of morphometric parameters drainage density and mean slope. The average RN obtained for small sub-basins within a river watershed indicate their most appropriate land uses. According to Rocha and Kurtz (2001), low RN values denote appropriate uses for agriculture (Class 1 ) while high RN values represent steeper slope areas, suited for forest occupation (Class 4). The intermediate values show areas suited for pastures (Class 2 ) or a mosaic of natural pastures and forests (Class 3 ). The present study used the map of suitable land uses produced for the EPA by Valle Junior (2008). In that study, the
EPA's amplitude of RN values (amplitude = highest RN - lowest RN) divided by the number of suitability classes (4) provided a class range. Then, for $\mathrm{RN} \leq$ class range the suitability allocation was to agriculture, for class range $<\mathrm{RN} \leq 2 \times$ class range the allocation was to pasture, for $2 \times$ class range $<\mathrm{RN} \leq 3 \times$ class range the allocation was to the mosaic of pastures and forests and for RN $>3 \times$ class range the allocation was to forests.

The environmental land use conflict considers the difference between the map of suitable ( $1 \leq$ "suitable" $\leq 4)$ and actual $(1 \leq$ "actual" $\leq 4)$ land uses. The areas where "suitable" - "actual" $\leq 0$ are not affected by conflicts ("suitable" - "actual" $=0$ ) or present a potential for agriculture or pasture expansion ("suitable" - "actual" < 0). Class-1 (low) conflict regions can be, for example, areas where the suitable use is pasture ("suitable" $=2$ ), but the actual use is crop production ("actual" = 1). Class-2 (moderate) and class-3 (severe) conflict regions may be places with appropriate use for the mix of pasture and forest ("suitable" $=3$ ) or forest ("suitable" $=4$ ), but that are currently occupied with crops ("actual" = 1). The review of Pacheco et al. (2018) alerted for the cascade of impacts derived from environmental land use conflicts. In the most severe cases, the resilience capacity may be affected and ultimately the ecosystem may collapse, a situation classified as environmental damage and punished in Brazil by Federal Law $n^{\circ}$ 6.938/ 1981, article 3, item II.

\subsection{Data processing}

Cross tabulation aimed to analyze the spatial relationship between the BI- and USLE-based soil loss maps, considering the role of geologic type and environmental land use conflicts. Therefore, a number of cross tabulations allowed to explore the coincidence between areas of identical BI and USLE soil losses in the Uberaba, Serra Geral and Marília formations, as well as between areas of BI soil losses and degree of environmental land use conflict within the aforementioned geologic types. A substantial coincidence among the BI and USLE maps would validate the brightness index results as remote sensed approach to soil loss assessment. A substantial match between large soil losses and severe environmental land use conflicts (e.g., classes 2 or 3 ) would link erosion to inadequate uses of land, confirming previous studies. The cross tabulation procedure resorted to the CROSSTAB tool of IDRISI SELVA 17.0 (https://clarklabs.org/). A reclassification of BI and USLE preceded the cross tabulation to set up equivalent soil loss classes among the erosion maps based on the corresponding histograms of pixel values. For the USLE map, the intervals differed among geologic formations considering the differences observed between the corresponding histograms. Thus, in the Marília formation the re-classified soil loss classes (t.ha ${ }^{-1}$. ano $^{-1}$ ) were $<4,4-6,6-8$ and $>8$; in the Uberaba formation the intervals were $<2.2,2.2-2.6$ and $>2.6$; and in the Serra Geral formation they were $<1.65,1.65-1.90$ and $>1.90$. For the BI map, the reclassification did not consider geology because the histograms were similar across formations. In this case, the reclassified classes were $<0.35,0.35-0.55$ and $>0.55$.

\subsection{Field data for the validation of BI and USLE soil losses}

Soil characteristics vary as function of pasture degradation, as noted, for example, in Valle Júnior et al. (2019). These authors documented a relationship between degradation and increases in the resistance to penetration, which triggers intensive erosion in the sequel. In this study, data on resistance to penetration obtained in the field at predefined locations within the EPA (Fig. 1) allowed validating the BI and USLE results. The maximum penetration resistance was measured using a PLG 1020 penetroLOG® penetrometer (Falker Automação, Porto Alegre, RS), manually operated with a penetration test depth range of $0-0.6 \mathrm{~m}$. The fieldwork involved 37 sites and the random probing of resistance within a 20 -meter buffer around each site. The validation procedure comprised three consecutive steps, repeated for the BI 


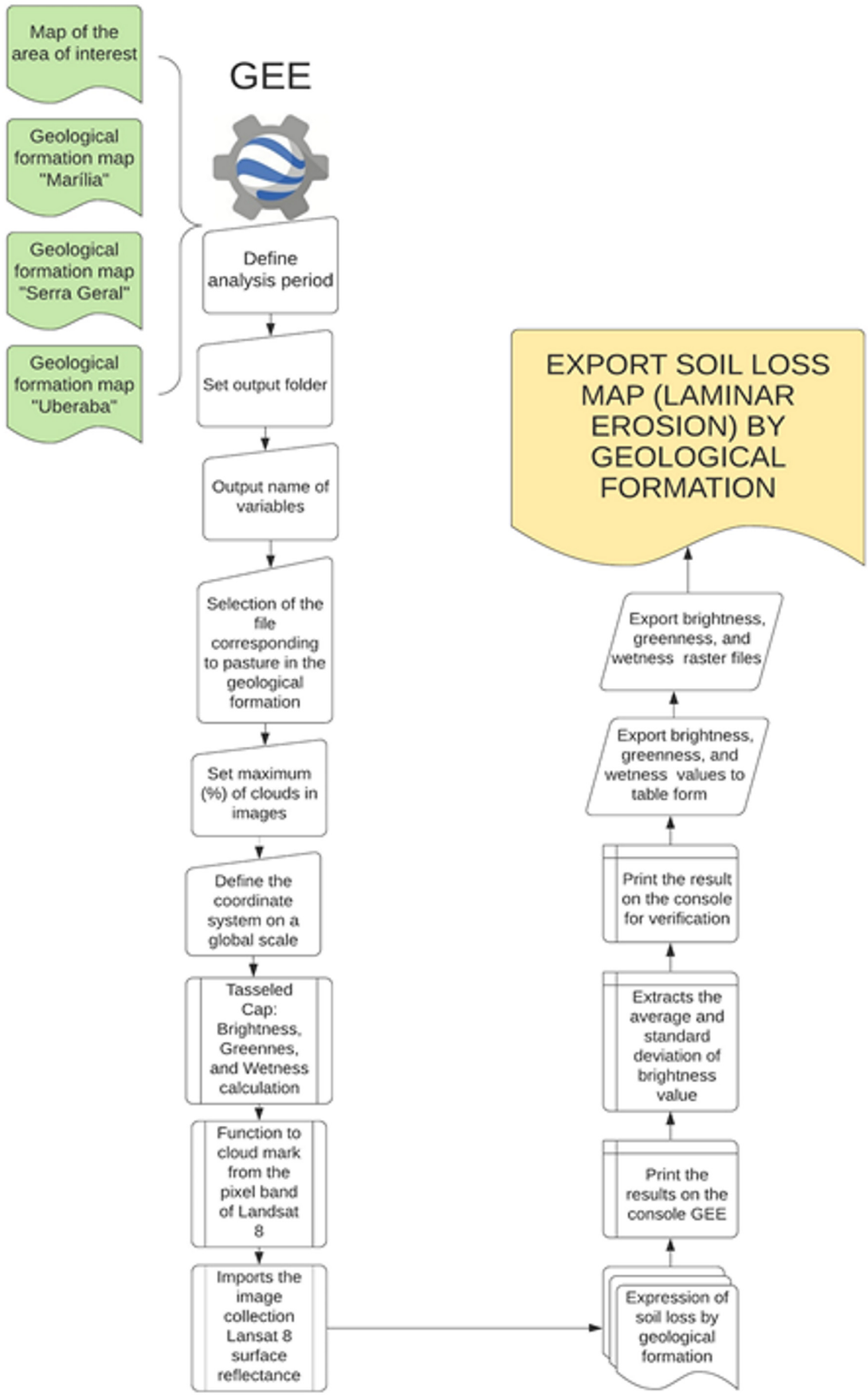



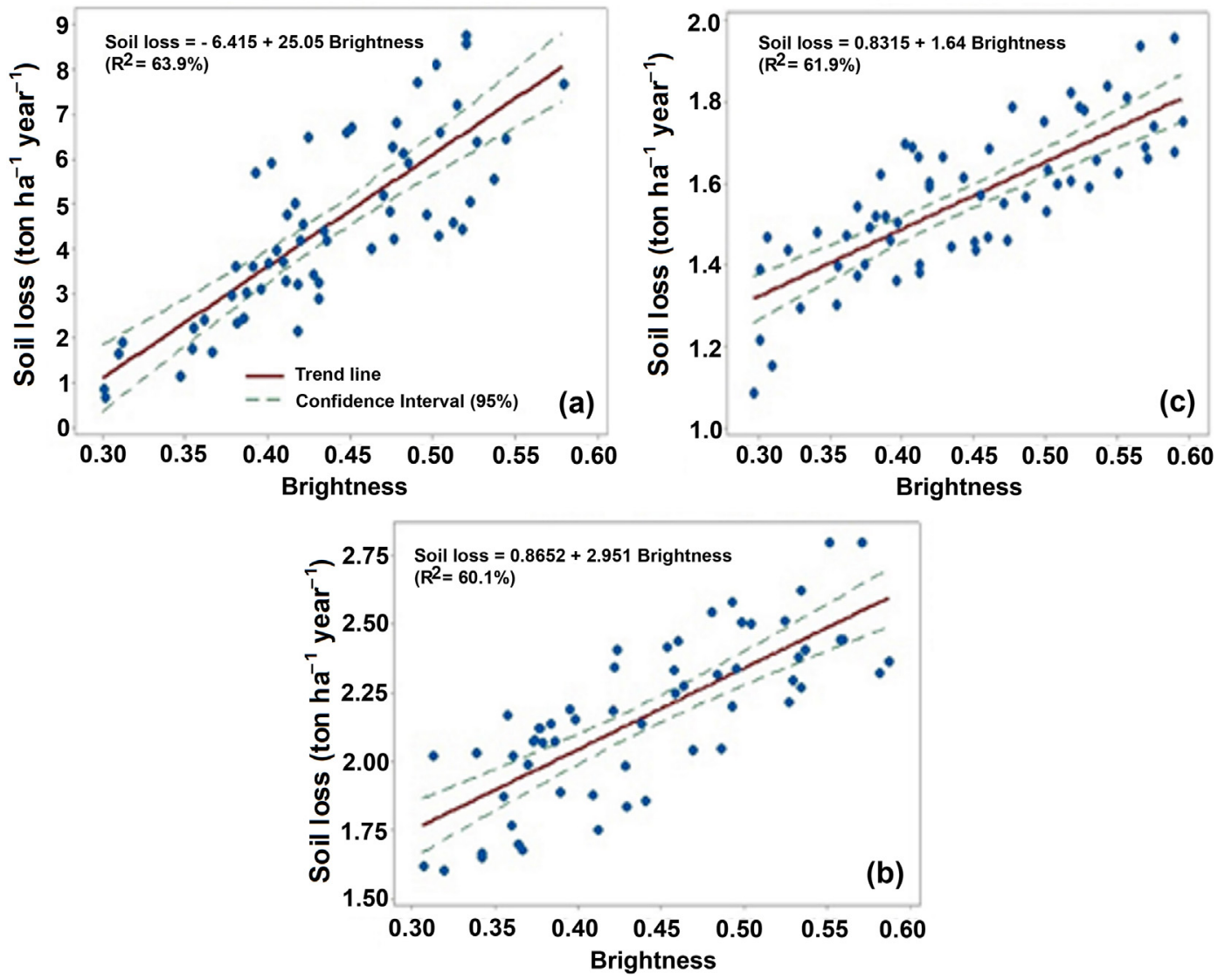

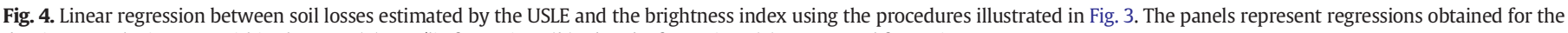
dominant geologic types within the EPA: (a) Marília formation; (b) Uberaba formation; (c) Serra Geral formation.

and USLE soil losses. Firstly, a comparison of measured resistances with thresholds defined for healthy and non-healthy (sensu lato) pastures in Valle Júnior et al. (2019), allowed classifying the pasture physiognomy in the site as "not-degraded" or "degraded", respectively (see the thresholds in Table S1 and the test sites of that work in Fig. 2). Accordingly, in the present study the values used to separate the "degraded" from the "not degraded" pastures were $4100 \mathrm{KPa}$ in the Marília and Uberaba formations and $3000 \mathrm{KPa}$ in the Serra Geral formation. Secondly, the sites classified as "degraded" assumed a reference soil loss, equivalent to the largest ranges observed in the studied area considering the geologic type $\left(>6 \mathrm{t} \mathrm{ha}^{-1}\right.$ year $^{-1}$ for the Marília formation; $>2.2 \mathrm{t} \mathrm{ha}^{-1}$ year $^{-1}$ for the Uberaba formation; and $>1.65 \mathrm{t} \mathrm{ha}^{-1}$ year $^{-1}$ for the Serra Geral formation; Section 2.5). Thirdly, an average soil loss determined within the 20-meter buffer and compared with the reference loss allowed to validate (if larger) or not validate (if smaller) the soil loss assessments (both BI and USLE). The validation of "not-degraded" sites followed a similar sequence of steps as those described above for the "degraded" sites.

\section{Results}

The scatter plots USLE-based soil loss versus Landsat 8-based brightness index represented in Fig. 4 for the Marília (a), Uberaba (b) and
Serra Geral (c) formations fit to straight lines with reasonable coefficients of determination $\left(\mathrm{R}^{2}>60 \%\right)$ and $p<0.001$ :

Marilia formation : Soil loss $=-6.415+25.05$ Brightness $\left(\mathrm{R}^{2}=63.9 \%\right)$

Uberaba formation : Soil loss $=0.8652+2.951$ Brightness $\left(\mathrm{R}^{2}=60.1 \%\right)$

Serra Geral formation : Soil loss $=0.8315+1.64$ Brightness $\left(\mathrm{R}^{2}=61.9 \%\right)$

Eqs. (6a)-(6c) applied to the brightness index raster maps produced by the GEE script (Appendix A; Fig. 3) allowed generating BI-based soil loss maps and compare them with the USLE-based counterparts. The results displayed in Fig. 5 show the losses estimated by the USLE in the left panels and the losses derived from the BI in the right panels. From the top to the bottom of that figure, the map fragments represent the soil losses in the Marília (a), Uberaba (b) and Serra Geral (c) formations. The analysis applies to pasture areas where different colors represent the soil loss classes predefined for the various geologic formations.

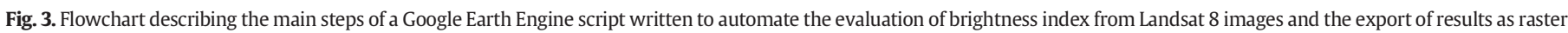
files, considering the spatial distribution of geologic types. 

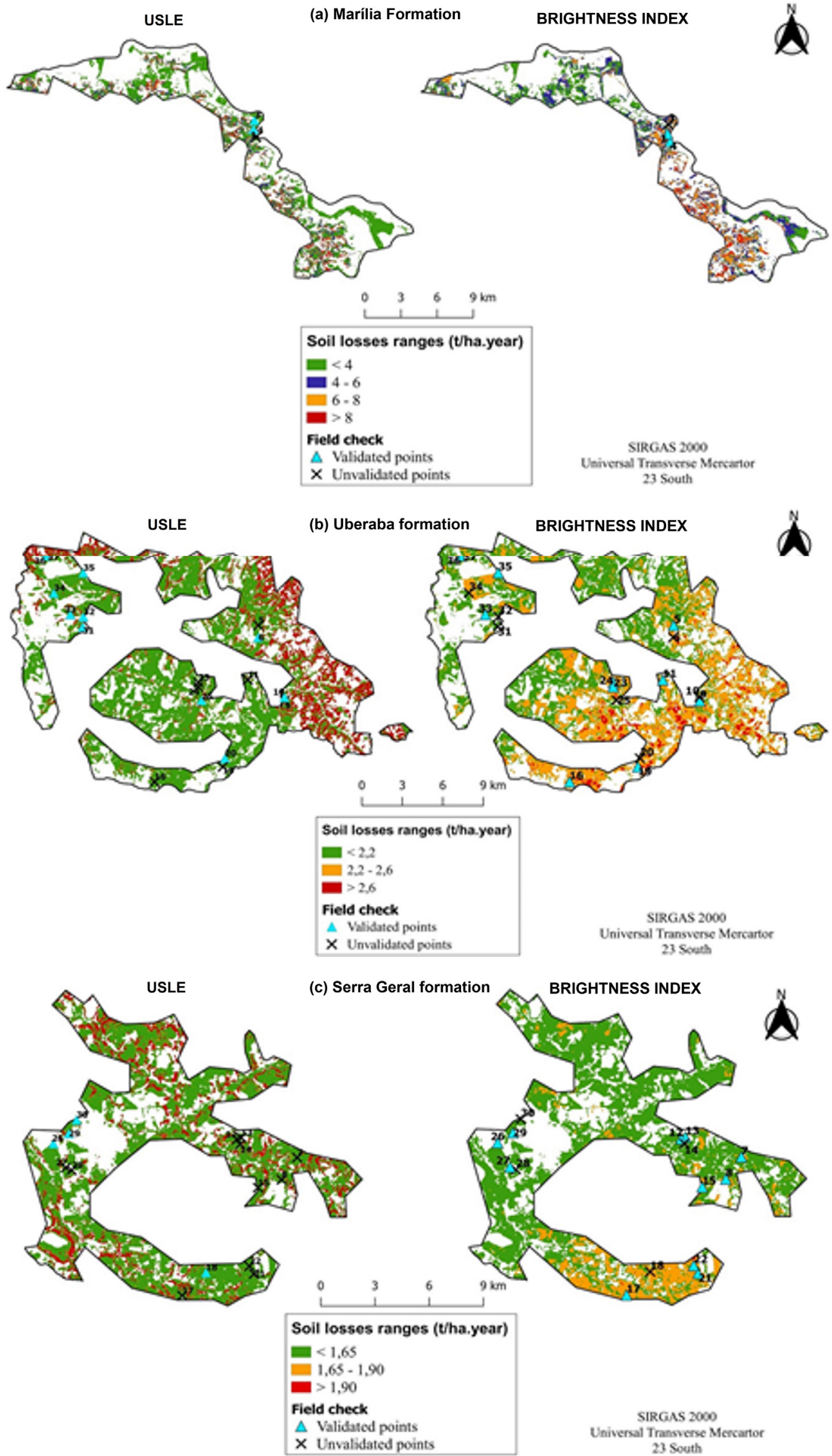
Table 2

Occupation of soil loss classes as estimated by the USLE and brightness index (BI) models within the geological formations of Uberaba River Environmental Protection Area.

\begin{tabular}{|c|c|c|c|c|c|c|}
\hline \multirow{2}{*}{$\begin{array}{l}\text { Geological } \\
\text { formation }\end{array}$} & \multirow[t]{2}{*}{ Model } & \multicolumn{4}{|c|}{ Loss classes ( $\mathrm{t} \mathrm{ha} \mathrm{y}^{-1}$ year $^{-1}$ ) } & \multirow{2}{*}{$\begin{array}{l}\text { Total area } \\
\text { (ha) }\end{array}$} \\
\hline & & $<4$ & $4-6$ & $6-8$ & $>8$ & \\
\hline \multirow[t]{2}{*}{ Marília } & $\mathrm{BI}$ & 1772.345 & 1778.14 & 1043 & 216.25 & 4810.41 \\
\hline & USLE & 3218.75 & 842.32 & 498 & 250.49 & 4810.41 \\
\hline \multirow{2}{*}{$\begin{array}{l}\text { Geological } \\
\text { formation }\end{array}$} & \multirow[t]{2}{*}{ Model } & \multicolumn{4}{|c|}{ Loss classes ( $\mathrm{t} \mathrm{ha}{ }^{-1}$ year $^{-1}$ ) } & \multirow{2}{*}{$\begin{array}{l}\text { Total area } \\
\text { (ha) }\end{array}$} \\
\hline & & $<2.2$ & & 2.6 & $>2.6$ & \\
\hline \multirow[t]{2}{*}{ Uberaba } & $\mathrm{BI}$ & \multirow{2}{*}{\multicolumn{2}{|c|}{$\begin{array}{r}8151.58 \\
1207333\end{array}$}} & 7550.92 & 838.80 & \multirow{2}{*}{$\begin{array}{l}16,541.30 \\
16,541.30\end{array}$} \\
\hline & USLE & & & 9.50 & 3558.52 & \\
\hline \multirow{2}{*}{$\begin{array}{l}\text { Geological } \\
\text { formation }\end{array}$} & \multirow[t]{2}{*}{ Model } & \multicolumn{4}{|c|}{ Loss classes $\left(\mathrm{t} \mathrm{ha}^{-1}\right.$ year $\left.^{-1}\right)$} & \multirow{2}{*}{$\begin{array}{l}\text { Total area } \\
\text { (ha) }\end{array}$} \\
\hline & & $<1.65$ & 1.65 & .90 & $>1.90$ & \\
\hline \multirow[t]{2}{*}{ Serra Geral } & $\mathrm{BI}$ & 6765.88 & 1513 & & 5.35 & 8285.05 \\
\hline & USLE & 6463.7 & 454 & & 1366.82 & 8285.05 \\
\hline
\end{tabular}

The white areas inside the fragments (no evaluation of soil loss) represent the other uses.

In the Marília formation (Fig. 5a), the soil losses $<6 \mathrm{tha}^{-1}$ year $^{-1}$ dominate the BI and USLE estimates, representing $84.4 \%$ and $73.8 \%$ of the EPA, respectively (Table 2). However, the contribution of larger losses $\left(6-8 \mathrm{tha}^{-1}\right.$ year $\left.^{-1}\right)$ is noticeable in the BI model (this class covers $21.4 \%$ of the area). In the Uberaba and Serra Geral formations, the soil losses are generally lower than in the Marilia formation. In the Uberaba formation (Fig. $5 \mathrm{~b}$ ), the dominant losses are $<2.6 \mathrm{t} \mathrm{ha}^{-1}$ year $^{-1}$ because they occupy $94.92 \%$ (BI) or $78.48 \%$ (USLE) of the EPA. However, when estimated by the USLE the class $>2.6 \mathrm{tha}^{-1}$ year $^{-1}$ is more important than the class 2.2-2.6 t ha ${ }^{-1}$ year $^{-1}$, because the former occupies $21.5 \%$ of the EPA while the later occupies solely 5.5\%. Finally, in the Serra Geral Formation (Fig. 5c) the dominance of soil losses is for the classes $<1.65 \mathrm{t} \mathrm{ha}^{-1}$ year $^{-1}$, with $77.64 \%$ and $81.27 \%$ coverage estimated with the BI and USLE models, respectively. As in the Uberaba formation, the class representing the larger losses $\left(>1.9 \mathrm{t} \mathrm{ha}^{-1}\right.$ year $\left.^{-1}\right)$ covers more area (16.5\%) than the antecedent class (1.65-1.9 $\mathrm{t} \mathrm{ha}^{-1}$ year $\left.^{-1} ; 5.5 \%\right)$. Overall, the soil loss assessments are generally comparable among the $\mathrm{BI}$ and USLE models, but some discrepancies occur at the larger values.

The results of cross tabulation involving the spatial distributions of $\mathrm{BI}$ soil losses (right panels in Fig. 5) and USLE (left panels) are depicted in Tables S2-S4 (results in hectare) as well as in Tables S2a-S4a (results in percentage) of Supplementary Materials. They indicate a coincidence in the spatial classification of soil loss classes, of $39.54 \%$ in the Marília formation, $43.92 \%$ in the Uberaba formation and $63.24 \%$ in the Serra Geral formation. These values represent the sums of main diagonals in Tables S2a-S4a. The values outside the main diagonals represent discrepant classifications. A thorough analysis of these values show the larger discrepancies related with misclassification among adjacent soil loss classes, especially among the lower loss classes. These divergences correspond to transition effects that the models were unable to harmonize. In general, the BI model interprets some areas classified by the USLE in the lowest loss class as belonging to the next larger class. In the Marília formation, this transition effect affected $24.93 \%$ of the areas, in the Uberaba formation $31.45 \%$ and in the Serra Geral formation $15.25 \%$. The USLE also included in the next larger class some areas classified by the BI model in the lowest loss class, but the extent was much smaller (4.71\% in the Marília formation, $1.38 \%$ in the Uberaba formation and $4.96 \%$ in the Serra Geral formation). If these transitional areas were included in the coincident areas, the overall coincidence would raise to $69.18 \%$ in the Marília formation, $76.75 \%$ in the Uberaba formation and $83.45 \%$ in the Serra Geral formation.
Table 3

Soil losses within the geological formations of Uberaba River Basin Environmental Protection Area (EPA), as estimated by the USLE and brightness index (BI) models. The values represent soil losses in $\mathrm{t} \mathrm{ha}^{-1}$ year $^{-1}$.

\begin{tabular}{llllrlr}
\hline $\begin{array}{l}\text { Geological } \\
\text { formation }\end{array}$ & Model & Minimum & Mean & Maximum & $\begin{array}{l}\text { Standard } \\
\text { deviation }\end{array}$ & Amplitude \\
\hline Marília & BI & 0.01 & 4.57 & 10.49 & 1.96 & 10.48 \\
& USLE & 0.01 & 3.18 & 26.64 & 2.69 & 26.63 \\
Uberaba & BI & 1.08 & 2.19 & 3.11 & 0.24 & 1.12 \\
& USLE & 0.03 & 1.89 & 25.89 & 1.75 & 25.85 \\
Serra & BI & 1.05 & 1.53 & 1.96 & 0.12 & 0.48 \\
Geral & USLE & 0.03 & 1.24 & 74.80 & 1.02 & 74.77 \\
\hline
\end{tabular}

Additional comparisons among the BI and USLE results taken from the data presented in Table 3 show the average BI losses generally higher than the USLE losses in all geological formation (43.7\% larger in the Marília formation; $15.9 \%$ in the Uberaba formation and $23.4 \%$ in the Serra Geral formation). On the other hand, the soil loss ranges are wider when the estimates come from the USLE method, because the maximum values are much larger in this case $(26.64 \gg 10.69$ in the Marília Formation; $25.89 \gg 3.11$ in the Uberaba formation; $74.8 \gg 1.96$ in the Serra Geral formation). This discrepancy probably occurs because the $\mathrm{BI}$ losses derive from regression equations that capture the trend ( $\approx 60 \%$ of observed variance) but fail to capture the residuals (the remaining 40\%). However, the divergence among the average soil losses probably relates with the aforementioned transitional effects and indicates an overestimation produced by the BI or an underestimation produced by the USLE. A more conclusive statement about this deviation will come with the analysis of field validation results, presented below.

The cross tabulation of soil loss classes (BI results) and classes of environmental land use conflict are illustrated in Fig. 6 and listed in Tables S5-S7 (values in hectare) or in Tables S5a-S7a (values in percentage) of the Supplementary materials. As expected, the results showed a general relationship between no conflict or insipient conflicts and small soil losses, as well as between severe conflicts and large soil losses. For example, in the Marília formation the areas affected by the lowest soil losses $\left(<4 \mathrm{t} \mathrm{ha}^{-1}\right.$ year $\left.^{-1}\right)$ represent $31.8 \%$ of the no conflict and $39.5 \%$ of Class 1 conflict landscapes, while the areas affected by the largest losses ( $>8 \mathrm{t} \mathrm{ha}^{-1}$ year $^{-1}$ ) occupy solely 4.67 and $2.81 \%$ of those landscapes. This scenario reverses in the Class 2 conflict landscape, where the areas of lowest and highest soil losses share 4.79 and $20.78 \%$ of those spaces, respectively. Similar conclusions hold for the Marília and Serra Geral formations, regarding the dominance of small soil losses in no conflict and Class 1 conflict landscapes. However, the results for the Class 2 conflict are somewhat divergent from the expectations. In the Uberaba formation, the intermediate soil loss class $\left(2.2-2.6 \mathrm{tha}^{-1} \mathrm{year}^{-1}\right)$ replaces the largest class because it occupies $73.06 \%$ of Class 2 conflict areas. In the Serra Geral formation, the situation is even more striking because Class 2 conflict landscapes remain mostly occupied $(82.05 \%)$ with the lowest soil loss class $\left(<1.65 \mathrm{tha}^{-1-}\right.$ year $^{-1}$ ). These results suggest differences in the sensitivity of geologic formations to environmental land use conflicts, in the sequence Marília > Uberaba $\gg$ Serra Geral.

The field validation of BI and USLE soil losses illustrated in Fig. 5 and described in Table 4 makes evident the better performance of BI relative to the USLE, because the number of sites that validate the first model is $24(64.86 \%)$ while that number in the second case is 19 (51.35\%). These results allow answering the question of whether the BI overestimated the mean soil losses or the USLE underestimated them. The higher performance of the BI foresees underestimated USLE soil losses. However, regardless the model the performances are modest suggesting the necessity to improve soil loss estimates using cartographic methods (either the BI or the ULSE) to improve the validation performances. 


\section{BRIGHTNESS INDEX}

(a) Marília Formation
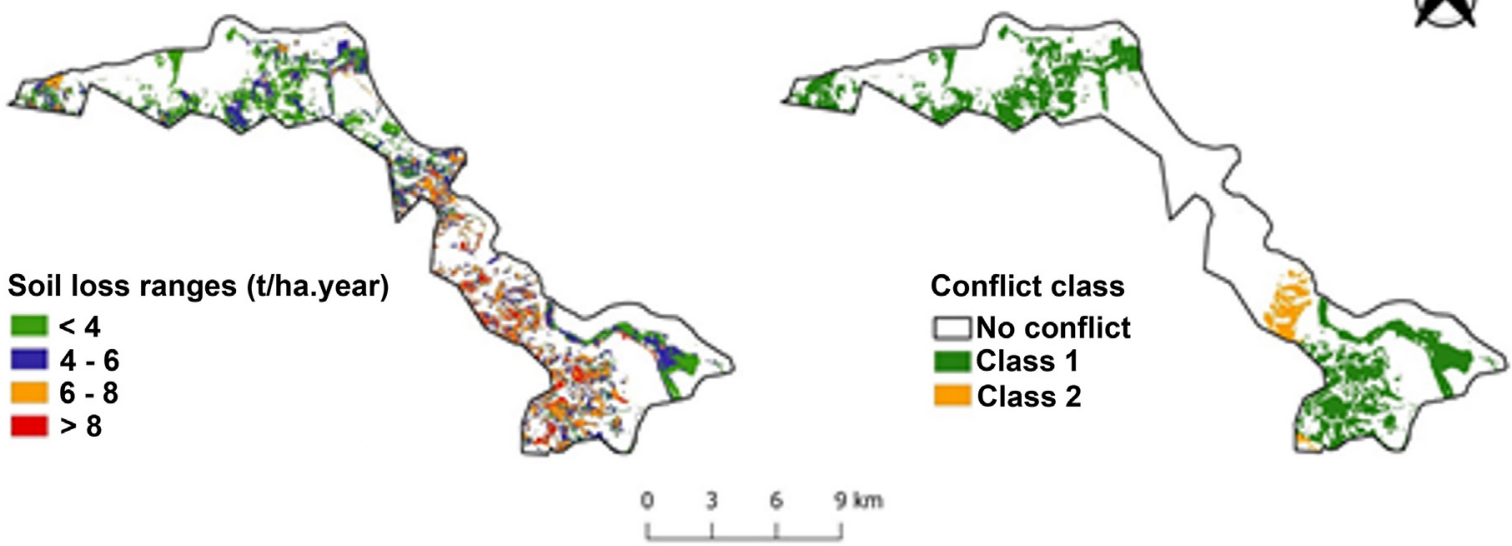

BRIGHTNESS INDEX

(b) Uberaba Formation

\section{CONFLICT}
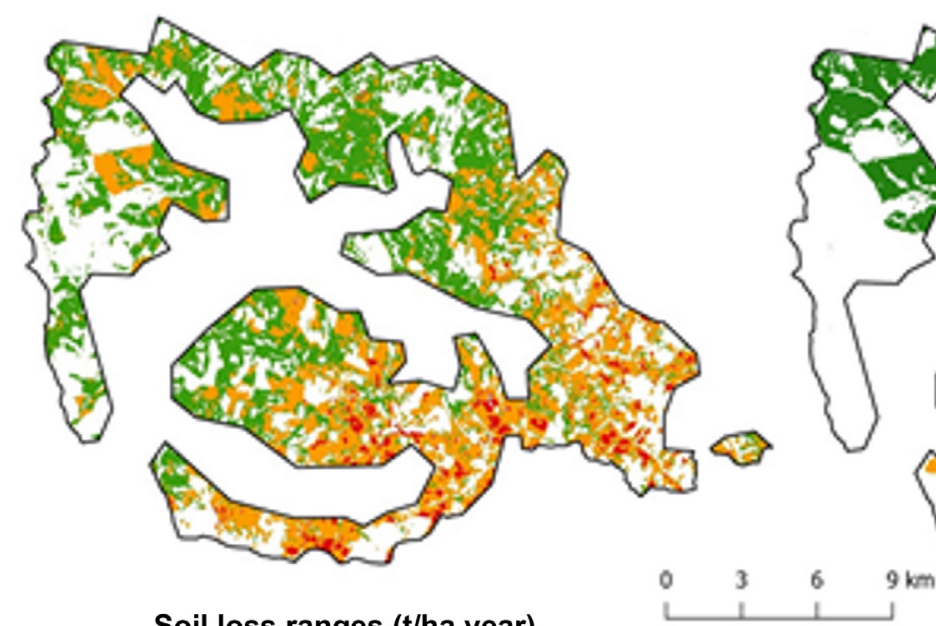

Soil loss ranges ( $t /$ ha.year)

$$
\begin{aligned}
& <2.2 \\
& 2.2-2.6 \\
& >2.6
\end{aligned}
$$

BRIGHTNESS INDEX

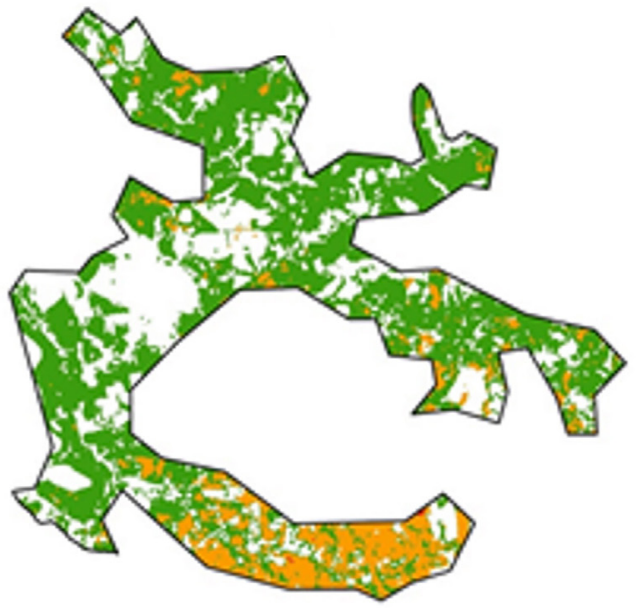

Soil loss ranges (t/ha.year)

$\square<1.65$

$1.65-1.9$

- $>1.9$

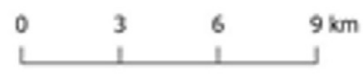
is

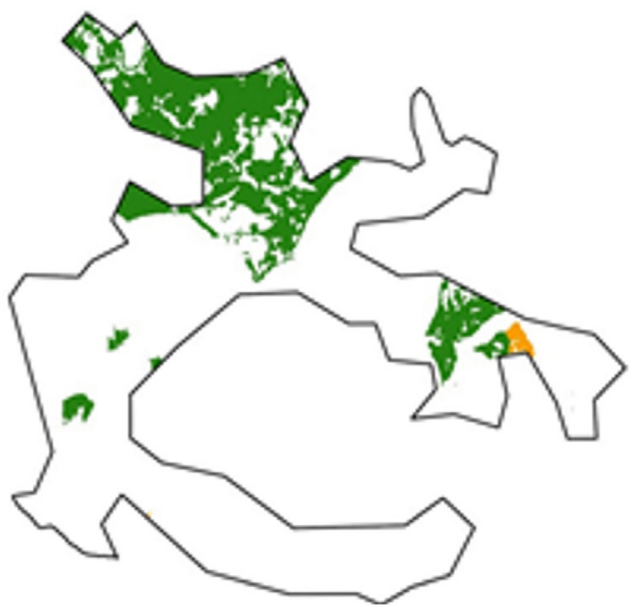

Conflict class

$\square$ No conflict

Class 1

Class 2 
Table 4

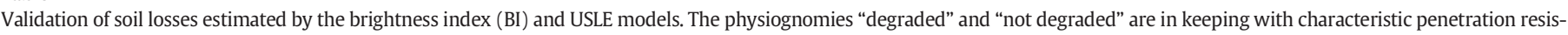

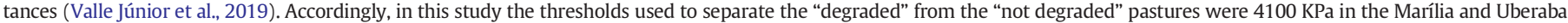

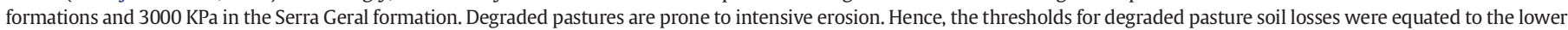

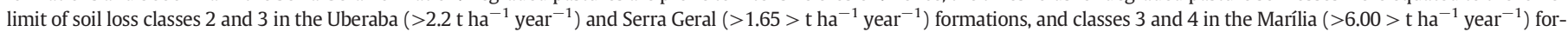
mation. Figs. 1, 2 and 5 link the data below to the ground truth sites, the geologic formations and soil losses/validation, respectively.

\begin{tabular}{|c|c|c|c|c|c|c|c|c|c|}
\hline \multirow[t]{3}{*}{$\begin{array}{l}\text { Geologic } \\
\text { formation }\end{array}$} & \multirow[t]{3}{*}{$\begin{array}{l}\text { Ground truth } \\
\text { site }\end{array}$} & \multirow{3}{*}{$\begin{array}{l}\text { X UTM } \\
\text { coordinate } \\
\mathrm{m}\end{array}$} & \multirow{3}{*}{$\begin{array}{l}\text { Y UTM } \\
\text { coordinate } \\
\mathrm{m}\end{array}$} & \multirow{3}{*}{$\begin{array}{l}\text { Maximum penetration } \\
\text { resistance } \\
\\
(\mathrm{KPa})\end{array}$} & \multirow[t]{3}{*}{ Physiognomy } & \multicolumn{2}{|c|}{$\begin{array}{l}\text { Brightness index (BI) } \\
\text { model }\end{array}$} & \multicolumn{2}{|c|}{ USLE model } \\
\hline & & & & & & $\begin{array}{l}\text { Mean soil } \\
\text { loss }\end{array}$ & Validation & $\begin{array}{l}\text { Mean soil } \\
\text { loss }\end{array}$ & Validation \\
\hline & & & & & & $\begin{array}{l}\text { t ha }^{-1} \\
\text { year }^{-1}\end{array}$ & & $\begin{array}{l}\text { t ha }^{-1} \\
\text { year }^{-1}\end{array}$ & \\
\hline \multirow[t]{3}{*}{ Marília } & 1 & 209,623 & $7,831,660$ & 3567 & Not degraded & 3,35 & Validated & 1,08 & Validated \\
\hline & 3 & 209,701 & $7,832,444$ & 6094 & Degraded & 4,64 & Not validated & 6,23 & Validated \\
\hline & 4 & 209,835 & $7,830,995$ & 5883 & Degraded & 6,8 & Validated & 1,41 & Not validated \\
\hline \multirow{19}{*}{ Uberaba } & 5 & 205,942 & $7,827,190$ & 4288 & Degraded & 2,28 & Validated & 0,71 & Not validated \\
\hline & 6 & 205,919 & $7,826,281$ & 3542 & Not degraded & 2,52 & Not validated & 0,53 & Validated \\
\hline & 9 & 207,890 & $7,821,435$ & 4265 & Degraded & 2,3 & Validated & 0,76 & Not validated \\
\hline & 10 & 207,868 & $7,821,468$ & 3147 & Not degraded & 2,31 & Not validated & 0,62 & Validated \\
\hline & 11 & 205,143 & $7,823,030$ & 6384 & Degraded & 2,27 & Validated & 0,62 & Not validated \\
\hline & 16 & 198,223 & $7,815,236$ & 4560 & Degraded & 2,3 & Validated & 1,06 & Not validated \\
\hline & 19 & 203,295 & $7,816,385$ & 5754 & Degraded & 2,64 & Validated & 0,37 & Not validated \\
\hline & 20 & 203,448 & $7,817,031$ & 3990 & Not degraded & 2,43 & Not validated & 0,68 & Validated \\
\hline & 23 & 201,472 & $7,822,821$ & 5940 & Degraded & 2,41 & Validated & 0,72 & Not validated \\
\hline & 24 & 201,461 & $7,822,495$ & 4428 & Degraded & 2,66 & Validated & 0,7 & Not validated \\
\hline & 25 & 201,712 & $7,821,471$ & 3993 & Not degraded & 2,44 & Not validated & 0,73 & Validated \\
\hline & 31 & 192,893 & $7,827,091$ & 2763 & Not degraded & 2,25 & Not validated & 1,42 & Validated \\
\hline & 32 & 192,941 & $7,827,849$ & 4068 & Not degraded & 2,16 & Validated & 0,31 & Validated \\
\hline & 33 & 191,979 & $7,828,026$ & 3743 & Not degraded & 2,07 & Validated & 1,17 & Validated \\
\hline & 34 & 190,754 & $7,829,669$ & 3539 & Not degraded & 2,33 & Not validated & 0,95 & Validated \\
\hline & 35 & 192,931 & $7,831,216$ & 3258 & Not degraded & 2,07 & Validated & 0,65 & Validated \\
\hline & 36 & 190,142 & $7,832,509$ & 2320 & Not degraded & 2,1 & Validated & 0,46 & Validated \\
\hline & 37 & 190,308 & $7,832,809$ & 2681 & Not degraded & 2,51 & Not validated & 1,54 & Validated \\
\hline & 38 & 191,107 & $7,833,586$ & 3314 & Not degraded & 2,54 & Not validated & 1,73 & Validated \\
\hline \multirow[t]{15}{*}{ Serra Geral } & 7 & 204,960 & $7,824,394$ & 3387 & Degraded & 1,67 & Validated & 0,79 & Not validated \\
\hline & 8 & 204,098 & $7,823,132$ & 5445 & Degraded & 1,65 & Validated & 0,75 & Not validated \\
\hline & 12 & 201,835 & $7,825,495$ & 5926 & Degraded & 1,65 & Validated & 0,51 & Not validated \\
\hline & 13 & 201,862 & $7,825,523$ & 4831 & Degraded & 1,65 & Validated & 0,73 & Not validated \\
\hline & 14 & 201,804 & $7,825,156$ & 7258 & Degraded & 1,58 & Not validated & 0,84 & Not validated \\
\hline & 15 & 202,790 & $7,822,678$ & 6454 & Degraded & 1,74 & Validated & 0,17 & Not validated \\
\hline & 17 & 198,596 & $7,816,517$ & 3565 & Degraded & 1,73 & Validated & 0,69 & Not validated \\
\hline & 18 & 199,911 & $7,817,842$ & 2696 & Not degraded & 1,67 & Not validated & 0,57 & Validated \\
\hline & 21 & 202,569 & $7,817,762$ & 3908 & Degraded & 1,71 & Validated & 0,43 & Not validated \\
\hline & 22 & 202,315 & $7,818,201$ & 3423 & Degraded & 1,71 & Validated & 0,7 & Not validated \\
\hline & 26 & 191,459 & $7,825,199$ & 2593 & Not degraded & 1,59 & Validated & 1,1 & Validated \\
\hline & 27 & 192,146 & $7,823,820$ & 2836 & Not degraded & 1,4 & Validated & 0,68 & Validated \\
\hline & 28 & 192,476 & $7,823,670$ & 3244 & Degraded & 1,38 & Not validated & 0,78 & Not validated \\
\hline & 29 & 192,310 & $7,825,772$ & 1067 & Not degraded & 1,41 & Validated & 1,41 & Validated \\
\hline & 30 & 192,746 & $7,826,544$ & 3165 & Degraded & 1,49 & Not validated & 1,48 & Validated \\
\hline
\end{tabular}

\section{Discussion}

Soil losses differ as function of bedrock, because the physicochemical and mineralogical attributes of rocks and soils derived therefrom directly interfere with their erodibility (Barbosa et al., 2019). For example, higher hematite concentrations increase the soil resistance to erosion because the iron oxides promote better soil structure (Correa et al., 2008; Silva et al., 2020). In the Environmental Protection Area (EPA) of Uberaba River basin, geologic formations show distinct hematite concentrations $\left(\mathrm{g} \mathrm{kg}^{-1}\right)$, namely $10-199.7$ (Uberaba) $\approx 122.1-201.4$ (Marília) «275.0-359.4 (Serra Geral) (Melo et al., 2003). The lower hematite concentrations of Marília and Uberaba formations, relative to the Serra Geral concentrations, are coherent with the higher resistances to penetration of Marília and Uberaba soils under degraded pastures ( $>4100 \mathrm{KPa}$ ) when compared with the values measured in Serra Geral soils under the same circumstances $(>3000 \mathrm{KPa}$ ), because higher resistances to penetration suggest more intensive soil erosion. The ranges of hematite content are also consistent with the sensitivity of erosion to environmental land use conflicts, which follows the sequence Marília > Uberaba $\gg$ Serra Geral formation.

Organic carbon is another soil component capable to control erosion susceptibility, because of its ability to generate and maintain granular aggregates that increase macro porosity and drainage and hence structure quality (Hancock et al., 2019; Mulumba and Lal, 2008; Serrano et al., 2016). In the EPA, Rodrigues et al. (2019) demonstrated the key role of organic carbon in the control of erosion, using Partial Least Squares - Path Modeling (PLS-PM). The authors equated erosion to $0.136 \times$ relief $-0.758 \times$ soil fertility $+0.346 \times$ environmental land use conflicts $+0.100 \times$ surface runoff, with soil fertility expressed as $0.8 \times$ organic carbon $+0.8 \times$ magnesium $+0.5 \times$ aluminium (and a few minor terms). In another study in the EPA, but more focused on water quality, Oliveira et al. (2019) also elected organic carbon as most prominent contributor to pasture conservation because of its marked influence on the PLS-PM results.

A striking factor capable to aggravate soil erosion in pasture areas is the condition of environmental land use conflict. The earlier studies on

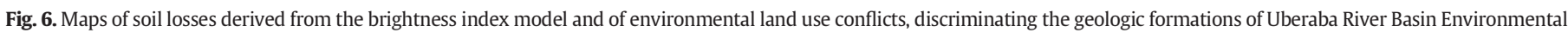
Protection Area (EPA): (a) Marília formation; (b) Uberaba formation; (c) Serra Geral formation. 
this subject related larger-magnitude conflicts with increased soil losses (Pacheco et al., 2018; Valle Junior et al., 2013). Recent studies in the EPA of Uberaba River basin allocated $37.61 \%$ of all degraded pastures to conflict areas that can be of Class 1 (mild) or 2 (moderate) depending on land suitability (Oliveira et al., 2019). In the same study, the authors estimated the largest percentage of degraded pasture in conflict areas in the Marília formation (67.61\%). The study by Rodrigues et al. (2019) elected land use conflicts and low soil fertility, under the dominant influence of organic carbon, to be the prominent cause of soil erosion in the EPA of Uberaba River basin.

The modeling of soil loss using the brightness index stands on the relationship between brightness and soil degradation. Bright soils are poor in organic matter (Bachaoui et al., 2014). Accordingly, uncovered soils or soils with sparse vegetation are perceived by high brightness values (Gleriani, 2003; Healey et al., 2005; Vorovencii, 2007). The brightness index is able to discriminate the vegetation from minerals in the soil, such as quartz or carbonates, especially when they are dry (Bannari et al., 2016; Baptista and Teobaldo, 2017; Demattê et al., 2014). In the EPA of Uberaba River basin, Rodrigues et al. (2019) reported a spatial correlation between brightness and soil loss, more evident in the dry season, using cross tabulation. Using a different approach, Saadat et al. (2014) managed to generate an erosion intensity map from the brightness index with $96 \%$ accuracy. In the present study, the brightness index model was capable to estimate better soil losses in pastureland than the widely used USLE, as detailed below.

Root architecture interferes with the resistance to penetration of a soil, affecting the growth of the crop and its productivity (Colombi et al., 2018). Intensive grazing interferes with soil compaction, amplifying the resistance to penetration already increased by the root structure, and promoting runoff and soil erosion in the sequel (Pilon et al., 2017). The determination of resistance to penetration using a field penetrometer has proven to be an important practical tool in predicting compaction in pastures (Benevenute et al., 2020). In the EPA of Uberaba River basin, resistance to penetration allowed checking the consistency of soil losses estimated by the BI and USLE models, in 37 predefined locations. The brightness index performed better (64.86\%) than the USLE (51.35\%). However, the results suggested improvements in the allocation of brightness values to soil losses.

In order to minimize the effects of disrespecting land suitability, namely soil erosion, it is necessary to embark on practical soil conservation measures and legal initiatives to repair socio-environmental damage such as the polluter-pays principle (Valera et al., 2017). If the environmental land use conflicts are framed as environmental damage, in the context of article 225, paragraph 3, of Federal Constitution of Brazil (1988), the so-called threefold liability applies: administrative liability (administrative fine imposed by the federated entities); civil liability (environmental compensation for environmental damage) and criminal liability (crime defined in Federal Law no. 9605/98). The imposition of environmental compensation relies on the simple proof of a causal link between the action or omission of action and the harmful event. The Theory of Integral Risk holds in these cases, which determines that even if the environmental damage arises from acts of God and force majeure, the indemnity obligation remains.

\section{Conclusions}

The Google Earth Engine (GEE) automatically extracted the brightness index from Landsat 8 images captured in 2018 across the pasture areas of Environmental Protection Area (EPA) of Uberaba River basin located in the state of Minas Gerais (Brazil), with discrimination of geologic type. The script specifically prepared to execute this task can be downloaded from the GEE platform. The linear regression between brightness index (BI) and USLE-based soil losses allowed the spatial recast of BI into BI soil losses with reasonable coefficients of determination $\left(R^{2}>60 \%\right)$. On average, the BI soil losses were 4.57 (Marília) $>2.19$ (Uberaba) > 1.53 (Serra Geral) $\mathrm{t} \mathrm{ha}^{-1}$ year $^{-1}$, while the USLE losses were 3.18 (Marília) $>1.89$ (Uberaba) $>1.24$ (Serra Geral) $\mathrm{t} \mathrm{ha}^{-1}$ year $^{-1}$. Thus, the average BI losses were larger than the USLE losses. The likely reason was that some values classified by the USLE model in Class 1 (e.g., $<4 \mathrm{t} \mathrm{ha}^{-1} \mathrm{year}^{-1}$ in the Marília formation), were interpreted by the BI model in Class 2 (4-6 t ha ${ }^{-1}$ year $^{-1}$ ), a behavior called "transition effect". However, the amplitude of BI losses were much smaller than the USLE losses. In this case, the justification was that the BI model captured the trend of USLE values through regression but not the residuals.

The BI model performed better than the USLE model because the validation of results using the resistance to penetration test in 37 locations returned a larger percentage of validated sites in the first case (64.86\%) than in the second case (51.35\%). The BI model was therefore used as reference in subsequent assessments, namely in the cross tabulation of losses and environmental land use conflicts. The results in this regard showed a general increase of soil losses in the moderate conflict areas (Class 2), but geologic formations responded differently to the inadequate land use changes that represent a conflict. The most sensitive formation was the Marília, followed by the Uberaba and finally by the Serra Geral formation.

The pastures affected by Class 2 conflicts occupy a total area of 1482.44 ha, mostly affected by excessive soil losses. These degraded pastures inherently relate with the anthropic action because they developed in the course of inadequate land use changes. In cases like these, the owner is responsible for the recovery of the land under the premises of Federal Law n ${ }^{\circ} 6.938 / 1981$ and the "polluter pays" principle. Future work should concentrate efforts in improving the performance of BI assessments of soil erosion as to aid the precise judgment of pasture degradation for the enforcement of land recovery.

\section{Funding}

This study was carried out within the framework of the Master's Degree in Environmental Science and Technology at the Federal University of Triângulo Mineiro (UFTM). The author affiliated to the Federal Institute of Triângulo Mineiro (IFTM), Renato Farias do Valle Júnior, acknowledges the funding through the research grant from the National Council for Scientific and Technological Development (CNPq). The author integrated in the CITAB research center was financed by funds from the Portuguese Science and Technology Foundation under the project UID/04033/2020. The author integrated in the CQVR was financed by funds from the Portuguese Science and Technology Foundation under the project UID/00616/2020. The research developed under the scope of CNPq-registered research groups "Manejo Sustentável de Bacias Hidrográficas" (IFTM, MG) and "Política de Uso do Solo - POLUS" (UNESP, SP).

\section{CRediT authorship contribution statement}

Alessandra Soares Vieira: Writing - original draft, Methodology, Investigation, Data curation, Software, Visualization. Renato Farias do Valle Junior: Conceptualization, Methodology, Writing - review \& editing, Resources, Supervision, Project administration. Vinicius Silva Rodrigues: Methodology, Investigation. Thiago Luiz da Silva Quinaia: Methodology, Investigation. Rafaella Gouveia Mendes: Resources, Funding acquisition, Writing - review \& editing. Carlos Alberto Valera: Formal analysis, Validation. Luís Filipe Sanches Fernandes: Formal analysis, Validation, Writing - review \& editing. Fernando António Leal Pacheco: Formal analysis, Validation, Visualization, Writing review \& editing.

\section{Declaration of competing interest}

The authors declare no conflicts of interest. The funders had no role in the design of the study, in the collection, analyses, or interpretation of data, in the writing of the manuscript, or in the decision to publish the results. 


\section{Appendix A. Programming the evaluation of brightness index in Google Earth Engine (GEE)}

The quantification of soil losses occurred separately in the three geological formations cropping out within the EPA (Marilia, Uberaba and Serra Geral), based on the interpretation of Landsat 8 OLI/T1_SR images for the year 2018. The processing of satellite images used a routine prepared in JavaScript in the GEE code editor menu (Gorelick et al., 2017). The script is available at: https://code.earthengine.google.com/?accept_ repo $=$ users/thiagoquinaia/Soil_loss.

In order to make the script simple, the proposed algorithm was divided into two sets, the first with non-fixed parameters where user interaction is possible, and the second with parameters fixed by the conceptual workflow (Fig. 3). The program code receives a file containing geospatial data in vector format (shapefile). For this study in the EPA of Uberaba River basin, the geospatial data comprised a shapefile containing the three geological formations as well as the pasture areas extracted from the land use and cover map (http://mapbiomas.org).

For processing of the non-fixed parameters (open data), following sequential steps were defined: a) Data entry, composed by the three Shapefiles of the occupied pasture in the geological formations loaded in the GEE platform; b) Definition of the analysis period corresponding to the year 2018 (script_lines 5 and 6); c) Institution identification of the folder of the output files (script_line 9) and the images and spreadsheet (script_lines 12 and 13); d) Selection of the pasture in the geological formation to be processed (script_line 17); e) Selection of the maximum permissible percentage of cloud cover in the image to be selected; f) choice of the geographic coordinate system, in this work, the World Geodetic System 84 (WGS 84) (script_line 36) was used.

When following the script of to the fixed parameters, the "print ()" function is noticeable right after each step as the objective is to print the result of each variable on the console for simple verfication. Therefore, below only the flow will be described in the respective programming lines: a) Calculation of the Tasseled Cap, with insertion of the equations that estimate the Brightness Index and add it to the image collection (script_lines 46 to 57); b) Rescheduling the pixel values (script_lines 64 to 68); c) Importing the image collection with the reflectance of the surface (script_lines 71 to 78); d) Insertion of the estimated equations of soil loss in the geological formations, Serra Geral (script_lines 84 to 94), Marilia (script_lines 97 to 118) and Uberaba (script_lines 121 to 142); e) Application of the equations in the image collection for the Serra Geral (script_lines 145 to 149), Marília (script_lines 150 to 153) and Uberaba (script_lines 154 to 157) formation; f) Intermediate processes for the realization of the zonal statistics, being, renamed in ascending order of Brightness (script_lines 161 to 163) and Loss of soil (script_lines 164 to 166), stacking the collection of images of Brightness (script_line 169) and loss of soil for the Serra Geral (script_line 170), Marília (script_line 171) and Uberaba (script_line 172) formation and automatically sets the scale in meters of the collection; g) Calculation of the zonal statistics, extracting the mean and standard deviation of the collection of images of Brightness (182 to 185) This function was important to extract the necessary values to elaborate the linear regressions that explain the loss of soil by the Brightness used in the script_lines (84 to 94), (97 to 118) and (121 to 142), h) Export the zonal statistics data in the ".csv" format (script_lines 191 to 197) and the raster files for each one, exported in ".GeoTiff" format, Brightness (script_lines 200 to 208), Loss of soil in the Serra Geral formation (script_lines 211 to 219), Marília (script_lines 222 to 230) and Uberaba (script_lines 233 to 241) for finishing in QGIS. Then, the Brightness raster was added to the visualization in the correct GEE environment and within the area of interest (script_lines 244 to 253).

\section{Appendix B. Supplementary data}

Supplementary data to this article can be found online at https://doi. org/10.1016/j.scitotenv.2021.146019.

\section{References}

Assefa, T.T., Jha, M.K., Tilahun, S.A., Yetbarek, E., Adem, A.A., Wale, A., 2015. Identification of erosion hotspot area using GIS and MCE technique for koga watershed in the upper blue Nile Basin. Ethiopia. Am. J. Environ. Sci. 11, 245-255. https://doi.org/10.3844/ ajessp.2015.245.255.

Bachaoui, M., Bachaoui, B., Lhissou, R., El Harti, A., El Ghmari, A., 2014. Modeling and mapping water erosion risks in the High Atlas of Morocco: the Atlas of BeniMellal as a case in point. Journal of Remote Sensing and GIS 2 (1), 2052-5583. http://arsgiso. org/publications/2014_2_1_BachaouiBachaou_Model.pdf.

Bannari, A., Kadhem, G., El-Battay, A., Hameid, N.A., Rouai, M., 2016. Assessment of land erosion and sediment accumulation caused by runoff after a flash-flooding storm using topographic profiles and spectral indices. Advances in Remote Sensing. 05, 315-354. https://doi.org/10.4236/ars.2016.54024.

Baptista, G.M. de M., Teobaldo, D., 2017. WorldView-2 sensor for the detection of hematite and goethite in tropical soils. Pesqui. Agropecu. Bras. 52, 1192-1202. https://doi. org/10.1590/S0100-204X2017001200008.

Barbosa, A. F.; Oliveira, E. F.; Mioto, C. L.; Paranhos Filho, A. C., 2015. The Application of the Universal Soil Loss Equation by Using Free and Available Softwares. Anuário do Inst. Geociências - UFRJ 38, 170.doi:10.11137/2015_1_170_179

Barbosa, R.S., Marques Júnior, J., Barrón, V., Martins Filho, M.V., Siqueira, D.S., Peluco, R.G., Camargo, L.A., Silva, L.S., 2019. Prediction and mapping of erodibility factors (USLE and WEPP) by magnetic susceptibility in basalt-derived soils in northeastern São Paulo state. Brazil. Environ. Earth Sci. 78, 1-12. https://doi.org/10.1007/s12665-0188015-0.

Benevenute, P.A.N., Morais, E.G., Souza, A.A., Vasques, I.C.F., Cardoso, D.P., Sales, F.R., Severiano, E.C., Homem, B.G.C., Casagrande, D.R., Silva, B.M., 2020. Penetration resistance: an effective indicator for monitoring soil compaction in pastures. Ecol. Indic. 117, 106647. https://doi.org/10.1016/j.ecolind.2020.106647.

Bhargava, R., Sarkar, D., Friess, D.A., 2020. A cloud computing-based approach to mapping mangrove erosion and progradation: case studies from the Sundarbans and French Guiana. Estuar. Coast. ShelfSci. 106798. https://doi.org/10.1016/j.ecss.2020.106798.

Caldas, A.M., Cristina, T., Pissarra, T., Araújo Costa, R.C., Cartaxo, F., Neto, R., Zanata, M., Da Boa, R., Parahyba, V., Filipe, L., Fernandes, S., António, F., Pacheco, L., 2018. Flood vulnerability, environmental land use conflicts, and conservation of soil and water: a study in the Batatais SP municipality, Brazil. Water 10, 1357. https://doi.org/ 10.3390/w10101357.

Chaves, H.M.L., 1994. Estimativa da erosão atual e potencial no Vale do São Francisco. Relatório Final de Consultoria. CODEVASF, Brasília.

Colombi, T., Torres, L.C., Walter, A., Keller, T., 2018. Feedbacks between soil penetration resistance, root architecture and water uptake limit water accessibility and crop growth - a vicious circle. Sci. Total Environ. 626, 1026-1035. https://doi.org/10.1016/j. scitotenv.2018.01.129.

Correa, M.M., Ker, J.C., Barrón, V., Fontes, M.P.F., Torrent, J., Curi, N., 2008. Caracterização de óxidos de ferro de solos do ambiente tabuleiros costeiro. Revista Brasileira de Ciência do Solo 32, 1017-1031. https://doi.org/10.1590/S0100-06832008000300011.

Costa, R.C.A., Pereira, G.T., Pissarra, T.C., Siqueira, D.S., Fernandes, L.F.S., Vasconcelos, V., Fernandes, L.A., Pacheco, F.A.L., 2019. Land capability of multiple-landform watersheds with environmental land use conflicts. Land Use Policy 81, 689-704. https:// doi.org/10.1016/j.landusepol.2018.11.041.

Cruz, B. S., 2003. Diagnóstico ambiental da bacia hidrográfica do Rio Uberaba. PhD Thesis. Universidade Estadual Paulista, Campinas (SP), Brasil (180 pp.).

Demattê, J.A.M., Bellinaso, H., Romero, D.J., Fongaro, C.T., 2014. Morphological Interpretation of Reflectance Spectrum (MIRS) using libraries looking towards soil classification. Sci. Agric. 71, 509-520. https://doi.org/10.1590/0103-9016-2013-0365.

Desmet, P.J.J., Govers, G., 1996. A GIS procedure for automatically calculating the USLE LS factor on topographically complex landscape units. J. Soil Water Conserv. 51, 427-433.

Dong, J. Xiao, X., Menarguez, M.A., Zhang, G., Oin, Y., Thau, D., Biradar, C., Moore, B., 2016 Mapping paddy rice planting area in northeastern Asia with Landsat 8 images, phenology-based algorithm and Google Earth Engine. Remote Sens. Environ. 185, 142-154. https://doi.org/10.1016/j.rse.2016.02.016.

El Jazouli, A., Barakat, A., Khellouk, R., Rais, J., El Baghdadi, M., 2019. Remote sensing and GIS techniques for prediction of land use land cover change effects on soil erosion in the high basin of the OumErRbia River (Morocco). Remote Sens. Appl. Soc. Environ. 13, 361-374. https://doi.org/10.1016/j.rsase.2018.12.004.

Fernandes, L.F.S., Seixas, F.J., Oliveira, P.C., Leitão, S., Moura, J.P., 2012. Climate-change impacts on nitrogen in a hydrographical basin in the northeast of Portugal. Fresenius Environ. Bull. 21 (12), 3643-3650.

Galdino, S., 2012. Estimativa da perda de terra sob pastagens cultivadas em solos arenosos da bacia hidrográfica do alto Taquari - MS/MT. Ph.D. Thesis. Faculdade de Engenharia Agrícola, Universidade Estadual de Campinas, Campinas.

Gleriani, J. M., 2003. Coeficientes da transformação espectral tasseledcap para uma cena com predomínio de latossolo roxo. In: Simpósio Brasileiro de Sensoriamento Remoto, 11., 2003, Belo Horizonte. Anais... Belo Horizonte: Inpe. 101-107.

Gorelick, N., Hancher, M., Dixon, M., Ilyushchenko, S., Thau, D., Moore, R., 2017. Google Earth Engine: planetary-scale geospatial analysis for everyone. Remote Sens. Environ. 202, 18-27. https://doi.org/10.1016/j.rse.2017.06.031.

Hancock, G.R., Kunkel, V., Wells, T., Martinez, C., 2019. Soil organic carbon and soil erosion understanding change at the large catchment scale. Geoderma 343, 60-71. https://doi. org/10.1016/j.geoderma.2019.02.012.

Healey, S.P., Cohen, W.B., Zhiqiang, Y., Krankina, O.N., 2005. Comparison of Tasseled Capbased Landsat data structures for use in forest disturbance detection. Remote Sens. Environ. 97, 301-310. https://doi.org/10.1016/j.rse.2005.05.009. 
Kauth, R. J. and Thomas, G. S., "The Tasselled Cap - A Graphic Description of the SpectralTemporal Development of Agricultural Crops as Seen by LANDSAT" (1976). LARS Symposia. Paper 159. http://docs.lib.purdue.edu/lars_symp/159.

Lopes, M.C., Martins, A.L.M., Simedo, M.B.L., Filho, M.V.M., Costa, R.C.A., Valle Júnior, R.F., Rojas, N.E.T., Sanches Fernandes, L.F., Pacheco, F.A.L., Pissarra, T.C.T., 2021. A case study of factors controlling water quality in two warm monomictic tropical reservoirs located in contrasting agricultural watersheds. Sci. Total Environ. 762, 144511.

Mccool, D.K., Brown, L.C., Foster, G.R., Mutchler, C.K., Meyer, L.D., 1987. Revised slope steepness factor for the Universal Soil Loss Equation. Transactions of the ASAE 30, 1387-1396. https://doi.org/10.13031/2013.30576@1987.

Melo, V.F., Corrêa, G.F., Maschio, P.A., Ribeiro, A.N., Lima, V.C. 2003. Importância das espécies minerais no potássio total da fração argila de solos do Triângulo Mineiro. Rev. Bras. Ciência do Solo 27, 09-10. https://doi.org/10.1590/s0100-06832003000500005.

Mhiret, D.A., Dagnew, D.C., Assefa, T.T., Tilahun, S.A., Zaitchik, B.F., Steenhuis, T.S., 2019. Erosion hotspot identification in the sub-humid Ethiopian highlands. Ecohydrol. Hydrobiol. 19, 146-154. https://doi.org/10.1016/j.ecohyd.2018.08.004.

Moreira, M.C., Pruski, F.F., de Oliveira, T.E.C., Pinto, F. de A. de C., da Silva, D.D., 2008 NetErosividade MG: erosividade da chuva em Minas Gerais. Rev. Bras. Ciência do Solo 32, 1349-1353. https://doi.org/10.1590/s0100-06832008000300042.

Mulumba, L.N., Lal, R., 2008. Mulching effects on selected soil physical properties. Soil Tillage Res. 98, 106-111. https://doi.org/10.1016/j.still.2007.10.011.

Nesper, M., Bünemann, E.K., Fonte, S.J., Rao, I.M., Velásquez, J.E., Ramirez, B., Hegglin, D., Frossard, E., Oberson, A., 2015. Pasture degradation decreases organic P content of tropical soils due to soil structural decline. Geoderma 257-258, 123-133. https:// doi.org/10.1016/j.geoderma.2014.10.010.

Novara, A., Pisciotta, A., Minacapilli, M., Maltese, A., Capodici, F., Cerdà, A., Gristina, L., 2018. The impact of soil erosion on soil fertility and vine vigor. A multidisciplinary approach based on field, laboratory and remote sensing approaches. Sci. Total Environ. 622-623, 474-480. https://doi.org/10.1016/j.scitotenv.2017.11.272.

Oliveira, C.F., do Valle Junior, R.F., Valera, C.A., Rodrigues, V.S., Sanches Fernandes, L.F., Pacheco, F.A.L., 2019. The modeling of pasture conservation and of its impact on stream water quality using Partial Least Squares-Path Modeling. Sci. Total Environ. 697, 134081. https://doi.org/10.1016/j.scitotenv.2019.134081.

Pacheco, F.A.L., Sanches Fernandes, L.F., 2016. Environmental land use conflicts in catchments: a major cause of amplified nitrate in river water. Sci. Total Environ. 548-549, 173-188. https://doi.org/10.1016/j.scitotenv.2015.12.155.

Pacheco, F.A.L., Sanches Fernandes, L.F., Valle Junior, R.F., Valera, C.A., Pissarra, T.C.T., 2018. Land degradation: multiple environmental consequences and routes to neutrality. Curr. Opin. Environ. Sci. Heal. 5, 79-86. https://doi.org/10.1016/j.coesh.2018.07.002.

Parente, L., Ferreira, L., Faria, A., Nogueira, S., Araújo, F., Teixeira, L., Hagen, S., 2017. Monitoring the Brazilian pasturelands: a new mapping approach based on the Landsat 8 spectral and temporal domains. Int. J. Appl. Earth Obs. Geoinf. 62, 135-143. https:// doi.org/10.1016/j.jag.2017.06.003.

Pilon, C., Moore, P.A., Pote, D.H., Pennington, J.H., Martin, J.W., Brauer, D.K., Raper, R.L., Dabney, S.M., Lee, J., 2017. Long-term effects of grazing management and buffer strips on soil erosion from pastures. J. Environ. Qual. 46, 364-372. https://doi.org/10.2134/ jeq2016.09.0378.

Pissarra, T.C.T., Valera, C.A., Costa, R.C.A., Siqueira, H.E., Filho, M.V.M., do Valle Júnior, R.F., Fernandes, L.F.S., Pacheco, F.A.L., 2019. A regression model of stream water quality based on interactions between landscape composition and riparian buffer width in small catchments. Water (Switzerland), 11 https://doi.org/10.3390/w11091757.

Renard, K. G., Foster, G. R., Weesies, G. A., McCool, D. K., Yoder, D. C., 1997. Predicting soil erosion by water: a guide to conservation planning with the Revised Universal Soil Loss Equation (RUSLE). [s.l.]: U.S. DepartamentofAgriculture.

Ribeiro, L. S., 2007. Quantificação de Perda de Solo por Erosão no município de Campos dos Goytacazes (RJ) através de Técnicas de Geoprocessamento. In: Simpósio Brasileiro de Sensoriamento Remoto; INPE; Florianópolis. 3039-3046.

Rocha, J. S. M., Kurtz, S. M. J. M., 2001. Manual de manejo integrado de bacias hidrográficas. Editora da UFSM, Santa Maria (pp. 282).

Rodrigues, V.S., do Valle Júnior, R.F., Sanches Fernandes, L.F. Pacheco, F.A.L. 2019. The assessment of water erosion using Partial Least Squares-Path Modeling: a study in a legally protected area with environmental land use conflicts. Sci. Total Environ. 691, 1225-1241. https://doi.org/10.1016/j.scitotenv.2019.07.216.

Saadat, H., Adamowski, J., Tayefi, V., Namdar, M., Sharifi, F., Ale-Ebrahim, S., 2014. A new approach for regional scale interrill and rill erosion intensity mapping using brightness index assessments from medium resolution satellite images. Catena 113, 306-313. https://doi.org/10.1016/j.catena.2013.08.012.

Sanches Fernandes, L.F., Fernandes, A.C.P., Ferreira, A.R.L., Cortes, R.M.V., Pacheco, F.A.L., 2018. A partial least squares - path modeling analysis for the understanding of biodiversity loss in rural and urban watersheds in Portugal. Sci. Total Environ. 626, 1069-1085. https://doi.org/10.1016/j.scitotenv.2018.01.127.

Serrano, J.M., Shahidian, S., da Silva, J.M., Carvalho, M., 2016. Monitoring of soil organic carbon over 10 years in a Mediterranean silvo-pastoral system: potential evaluation for differential management. Precis. Agric. 17, 274-295. https://doi.org/10.1007/ s11119-015-9419-4.

Silva, L.S., Marques Júnior, J., Barrón, V., Gomes, R.P., Teixeira, D.D.B., Siqueira, D.S. Vasconcelos, V., 2020. Spatial variability of iron oxides in soils from Brazilian sandstone and basalt. Catena 185, 104258. https://doi.org/10.1016/j.catena.2019.104258.

Stein, D.P., Donzelli, P.L., Gimenez, A.F., Ponçano, W.L., Lombardi Neto, F., 1987. Potencial de erosão laminar, natural e antrópico, na bacia do Peixe - Paranapanema. In: Simpósio Nacional de Controle de Erosão, 4, Marília. Anais... São Paulo: ABGE/ DAEE, pp. 105-135.

Tepanosyan, G.H., Asmaryan, S.G., Muradyan, V.S., Saghatelyan, A.K., 2017. Mapping maninduced soil degradation in Armenia's high mountain pastures through remote sensing methods: a case study. Remote Sens. Appl. Soc. Environ. 8, 105-113. https://doi. org/10.1016/j.rsase.2017.08.006.

Torres, F.N., Richter, R., Vohland, M., 2019. A multisensoral approach for high-resolution land cover and pasture degradation mapping in the humid tropics: a case study of the fragmented landscape of Rio de Janeiro. Int. J. Appl. Earth Obs. Geoinf. 78, 189-201. https://doi.org/10.1016/j.jag.2019.01.011.

Valera, C.A., Valle Junior, R.F., Varandas, S.G.P., SanchesFernandes, L.F., Pacheco, F.A.L., 2016. The role of environmental land use conflicts in soil fertility: a study on the Uberaba River basin. Brazil. Sci. Total Environ. 562, 463-473. https://doi.org/ 10.1016/j.scitotenv.2016.04.046.

Valera, C.A., Pissarra, T.C.T., Martins Filho, M.V., Valle Junior, R.F., Sanches Fernandes, L.F. Pacheco, F.A.L., 2017. A legal framework with scientific basis for applying the 'polluter pays principle' to soil conservation in rural watersheds in Brazil. Land Use Policy 66, 61-71. https://doi.org/10.1016/j.landusepol.2017.04.036.

Valera, C.A., Pissarra, T.C.T., Filho, M.V.M., do Valle Júnior, R.F., Oliveira, C.F., Moura, J.P., Fernandes, L.F.S., Pacheco, F.A.L., 2019. The buffer capacity of riparian vegetation to control water quality in anthropogenic catchments from a legally protected area: a critical view over the Brazilian new forest code. Water (Switzerland), 11 https:// doi.org/10.3390/w11030549.

Valle Junior, R. F., 2008. Diagnóstico de áreas de risco de erosão e conflito de uso dos solos na bacia do Rio Uberaba. 2008. Tese (Doutorado) - Curso de Agronomia (Produção Vegetal), Universidade Estadual Paulista, Jaboticabal (222 pp.).

Valle Junior, R.F., Galbiatti, J.A., Pissarra, T.C.T., Martins Filho, M.V., 2013. Diagnóstico do Conflito de Uso e Ocupação do Solo na Bacia do Rio Uberaba. Glob. Sci. Technol. 6 , 40-52. doi: 10.14688/1984-3801.v06n01a04

Valle Junior, R.F., Varandas, S.G.P., SanchesFernandes, L.F., Pacheco, F.A.L., 2014. Environmental land use conflicts: a threat to soil conservation. Land Use Policy 41 172-185. https://doi.org/10.1016/j.landusepol.2014.05.012.

Valle Junior, R.F., Varandas, S.G.P., Pacheco, F.A.L., Pereira, V.R., Santos, C.F., Cortes, R.M.V., Sanches Fernandes, L.F., 2015a. Impacts of land use conflicts on riverine ecosystems. Land Use Policy 43, 48-62. https://doi.org/10.1016/j.landusepol.2014.10.015.

Valle Junior, R.F., Varandas, S.G.P., Sanches Fernandes, L.F., Pacheco, F.A.L., 2015b. Multi criteria analysis for the monitoring of aquifer vulnerability: a scientific tool in environmental policy. Environ. Sci. Pol. 48, 250-264. https://doi.org/10.1016/j. envsci.2015.01.010.

Valle Júnior, R.F. do, Siqueira, H.E., Valera, C.A., Oliveira, C.F., Sanches Fernandes, L.F., Moura, J.P., Pacheco, F.A.L., 2019. Diagnosis of degraded pastures using an improved NDVI-based remote sensing approach: an application to the Environmental Protection Area of Uberaba River Basin (Minas Gerais, Brazil). Remote Sens. Appl. Soc. Environ. 14, 20-33. https://doi.org/10.1016/j.rsase.2019.02.001.

Valle, R.F., Varandas, S.G.P., Sanches Fernandes, L.F., Pacheco, F.A.L., 2014. Groundwater quality in rural watersheds with environmental land use conflicts. Sci. Total Environ. 493, 812-827. https://doi.org/10.1016/j.scitotenv.2014.06.068.

Vorovencii, I., 2007. Use of the "tasseled cap" transformation for the interpretation of satellite images. Cadastre Journal Revcad, [s. 1.], 7, 75-82.

Williams, J.R., 1975. Sediment routing for agricultural watersheds. J. Am. Water Resour. Assoc. 11, 965-974. https://doi.org/10.1111/j.1752-1688.1975.tb01817.x.

Wischmeier, W., Smith, D., 1978. Predicting rainfall erosion losses: a guide to conservation planning. [s.1.]: Department of Agriculture (67 pp.).

$\mathrm{Xu}, \mathrm{E}$., Zhang, H., 2016. Aggregating land use quantity and intensity to link water quality in upper catchment of Miyun Reservoir. Ecol. Indic. 66, 329-339. https://doi.org/ 10.1016/j.ecolind.2016.02.002

Zanchetta, A., Bitelli, G., Karnieli, A., 2016. Monitoring desertification by remote sensing using the Tasselled Cap transform for long-term change detection. Nat. Hazards 83, 223-237. https://doi.org/10.1007/s11069-016-2342-9. 